\title{
Long-term variations and trends in the simulation of the middle atmosphere 1980-2004 by the chemistry-climate model of the Meteorological Research Institute
}

\author{
K. Shibata and M. Deushi \\ Meteorological Research Institute, Tsukuba, Ibaraki 305-0052, Japan \\ Received: 11 May 2007 - Revised: 7 April 2008 - Accepted: 29 April 2008 - Published: 28 May 2008
}

\begin{abstract}
A middle-atmosphere simulation of the past 25 years (from 1980 to 2004) has been performed with a chemistry-climate model (CCM) of the Meteorological Research Institute (MRI) under observed forcings of seasurface temperature, greenhouse gases, halogens, volcanic aerosols, and solar irradiance variations. The dynamics module of MRI-CCM is a spectral global model truncated triangularly at a maximum wavenumber of 42 with 68 layers extending from the surface to $0.01 \mathrm{hPa}$ (about $80 \mathrm{~km}$ ), wherein the vertical spacing is $500 \mathrm{~m}$ from 100 to $10 \mathrm{hPa}$. The chemistry-transport module treats 51 species with 124 reactions including heterogeneous reactions. Transport of chemical species is based on a hybrid semi-Lagrangian scheme, which is a flux form in the vertical direction and an ordinary semi-Lagrangian form in the horizontal direction. The MRI-CCM used in this study reproduced a quasi-biennial oscillation (QBO) of about a 20-month period for wind and ozone in the equatorial stratosphere. Multiple linear regression analysis with time lags for volcanic aerosols was performed on the zonal-mean quantities of the simulated result to separate the trend, the QBO, the El Chichón and Mount Pinatubo, the 11-year solar cycle, and the El Niño/Southern Oscillation (ENSO) signals. It is found that MRI-CCM can more or less realistically reproduce observed trends of annual mean temperature and ozone, and those of total ozone in each month. MRI-CCM also reproduced the vertical multi-cell structures of tropical temperature, zonal-wind, and ozone associated with the QBO, and the mid-latitude total ozone QBO in each winter hemisphere. Solar irradiance variations of the 11-year cycle were found to affect radiation alone (not photodissociation) because of an error in making the photolysis lookup table. Nevertheless, though the heights of the maximum temperature (ozone) in the tropics are much higher (lower) than observations, MRI-CCM could reproduce the
\end{abstract}

Correspondence to: $\mathrm{K}$. Shibata

(kshibata@mri-jma.go.jp) second maxima of temperature and ozone in the lower stratosphere, demonstrating that the dynamic effect outweighs the photochemical effect there. The ENSO signals of annual mean temperature, zonal wind, and ozone are generally reproduced in the troposphere and below the middle stratosphere. The volcanic signals of temperature increase and ozone decrease are much overestimated for both El Chichón and Mount Pinatubo.

Keywords. Atmospheric composition and structure (Middle atmosphere - composition and chemistry) - Meteorology and atmospheric dynamics (General circulation; Middle atmosphere dynamics)

\section{Introduction}

The stratospheric ozone has decreased since the late 1970s because of the increase in the reactive chlorine produced from photodissociation of man-made chlorofluorocarbons (CFCs) and halons under strong ultraviolet (UV) radiation in the stratosphere. When the stratospheric temperature is very low and less than certain critical values (about $187 \mathrm{~K}$ and $195 \mathrm{~K}$ ) during winter to spring, polar stratospheric clouds (PSCs) appear, on the surfaces of which heterogeneous reactions proceed, leading to the alteration of normal gas-phase partitioning of odd nitrogen $\left(\mathrm{NO}_{\mathrm{y}}\right)$, odd chlorine $\left(\mathrm{ClO}_{\mathrm{y}}\right)$, and odd bromine $\left(\mathrm{BrO}_{\mathrm{y}}\right)$. The heterogeneous reactions, for example, convert reservoir species such as $\mathrm{HCl}$ and $\mathrm{ClONO}_{2}$ into active species such as $\mathrm{Cl}_{2}$ and hence enable catalytic cycles involving reactive nitrogen, chlorine, and bromine, i.e. $\mathrm{NO}_{\mathrm{x}}, \mathrm{ClO}_{\mathrm{x}}$, and $\mathrm{BrO}_{\mathrm{x}}$, to efficiently destroy ozone. The most prominent phenomenon associated with the combined effect of the halogen increase and PSCs is the Antarctic ozone hole (Chubachi, 1984; Farman et al., 1985) defined as the area of total ozone of less than 220 Dobson Units (DU). The ozone hole developed almost every year from the early 1980s to

Published by Copernicus Publications on behalf of the European Geosciences Union. 
the middle 1990s. Since then it has nearly saturated at very severe levels with small interannual variations except for a few years, when planetary waves propagating from the troposphere are unusually active. A similar severe ozone hole is expected to continue to appear up to about 2020 (Newman et al., 2006), even though the equivalent effective stratospheric chlorine (EESC) decreases after reaching a maximum value around 1998 (e.g. Randel and $\mathrm{Wu}, 2007$ ) unless the dynamic perturbation (wave activity) is unusually strong (e.g. Newman et al., 2004). This is because the decrease rate of the equivalent effective Antarctic stratospheric chlorine (EEASC) is expected to be very small up to about 2020, after which EEASC will diminish rather quickly (Newman et al., 2006). Similarly, severe ozone depletion occurs in the northern polar region if the winter stratospheric temperature is cold enough to form PSCs though not as frequently as in the Southern Hemisphere (e.g. Rex et al., 2006).

The increase in the well-mixed greenhouse gases (GHGs) such as $\mathrm{CO}_{2}, \mathrm{CH}_{4}$, and $\mathrm{N}_{2} \mathrm{O}$ due to human activities increases the net downward terrestrial radiation at the tropopause, and this radiative perturbation warms the troposphere and continent/ocean as global warming, and simultaneously cools the stratosphere. Both stratospheric cooling and tropospheric warming can crucially impact the stratospheric circulation because the tropospheric circulation change affects the generation of planetary and/or gravity waves, which changes the divergence of the waves propagating from below and, in turn, the mean meridional circulation (e.g. Sigmond et al., 2004; Butchart et al., 2006) in the stratosphere through downward control (Haynes et al., 1991). Ozone, a non-well-mixed GHG, also contributes to global warming through terrestrial radiation if it increases in the troposphere (Lacis et al., 1990). In contrast, a stratospheric ozone increase locally warms the stratosphere and simultaneously suppresses global warming in the troposphere through solar radiation. Conversely, a stratospheric ozone decrease induces cooling in the stratosphere as demonstrated in both polar regions (e.g. Randel and Wu, 1999). A change in the lower stratospheric $\mathrm{H}_{2} \mathrm{O}$ also affects the local radiative balance and is a possible contributor to stratospheric cooling (e.g. Forster and Shine, 1997). As a result, the variations in well-mixed and non-well-mixed GHGs force the stratosphere to change directly through radiation and indirectly through dynamics driven by the waves propagating from the troposphere.

Solar irradiance variations affect the stratosphere as well as the troposphere. The 11-year solar cycle is the most prominent cycle giving rise to large impacts on the stratospheric temperature (e.g. Scaife et al., 2000) and ozone (e.g. McCormack and Hood, 1996) through substantial irradiance variations of several percent at UV wavelengths. Though the total solar irradiance variations of the 11-year solar cycle are at most $0.1 \%$ (e.g. Lean et al., 1997), its signal can be detected from the upper stratosphere down to the surface in the observed geopotential data (e.g. Coughlin and Tung,
2004). Indeed, the 11-year solar-cycle effect on the upper stratosphere is readily understood as a direct result of the UV irradiance changes (e.g. Brasseur, 1993), but the mechanism of its effect on the middle and lower stratosphere is not necessarily well clarified. For example, Kodera and Kuroda (2002) demonstrated that the Brewer-Dobson circulation is weakened during the solar maximum through the wave-mean flow interaction in the subtropical upper stratosphere of the winter hemisphere, which induces warming and ozone increase in the tropical lower stratosphere. However, this mechanism cannot explain the observed minimum signals of temperature and ozone in the tropical middle stratosphere.

Huge volcanic eruptions eject large amounts of $\mathrm{SO}_{2}$ gas into the stratosphere, and the $\mathrm{SO}_{2}$ gas eventually condenses into volcanic sulfate aerosols through gas-to-particle conversion. Volcanic aerosols produce large perturbations in heterogeneous reactions on the aerosol surface as well as in radiative heating, and thereby heavily disturb the stratospheric chemistry and dynamics. Giant volcanic eruptions are sporadic but occasionally occur, at least a few times a century (e.g. Siebert and Simkin, 2002), and the volcanic aerosols from one eruption remain in the stratosphere for up to several years depending on its magnitude (Deshler et al., 2006), inducing crucial variations in ozone and temperature in the stratosphere. For example, after the Mount Pinatubo eruption in June 1991, the largest eruption in the 20th century, record low values (two standard deviations below a normal value, i.e. $-2 \sigma)$ of global $\left(65^{\circ} \mathrm{S}\right.$ to $\left.65^{\circ} \mathrm{N}\right)$ total ozone (e.g. Gleason et al., 1993) and anomalously warm $(+3 \sigma)$ zonal mean temperature in the middle stratosphere (e.g. Labitzke and McCormick, 1992) were observed.

Chemical transport models (CTMs) and chemistry-climate models (CCMs) are very useful for investigating stratospheric ozone or other constituent changes, albeit having different frameworks, because ozone and other constituents are prognostic variables in these models. CTMs are forced by observed or general circulation model (GCM)-generated meteorological fields without feedback between chemistry and dynamics through radiation, while CCMs use GCMgenerated meteorological fields with feedback. So far, timeslice or time-varying simulations have been made with CTMs focusing on the stratospheric ozone (e.g. Chipperfield, 1999; Hadjinicolaou et al., 2005; Stolarski et al., 2006) or with CCMs (e.g. Austin et al., 2003; Dameris et al, 2005; Tian and Chipperfield, 2005; Austin and Wilson, 2006; Garcia et al., 2007). CCMs of the stratosphere cover a wide range of integration periods with different complexities in the modules of chemistry and dynamics, and hence Austin et al. (2003) evaluated uncertainties and assessments of seven CCMs and one GCM using parameterized chemistry, with a particular focus on polar ozone. Following this, Eyring et al. (2006) made a similar intercomparison of thirteen CCMs' simulations, including the result of the Meteorological Research Institute (MRI), for the recent past over two decades or more under the specification of a common scenario of reference 1 (REF1) of 
Chemistry-Climate Model Validation Activity (CCMVal) for SPARC (Eyring et al., 2005). The REF1 scenario includes nearly all the observed forcings such as sea-surface temperature (SST), sea ice, well-mixed GHGs, halogens, solar cycle, and volcanic aerosols.

This study describes long-term variations and trends that appeared in the REF1 simulation from 1980 to 2004 by the chemistry-climate model of the Meteorological Research Institute (MRI-CCM), with different aspects from the analysis of Eyring et al. (2006). The simulation data used in this study is based on a new REF1 simulation, which differs from the data used in the intercomparison (Eyring et al., 2006) because the transport scheme for chemical constituents was thoroughly updated to decrease model biases in chemistry after the data had been submitted for the intercomparison. Multiple linear regression analysis was applied to the temperature, zonal wind, and ozone to objectively separate the trend, the QBO, the El Chichón and Mount Pinatubo, the 11year solar cycle, and El Niño/Southern Oscillation (ENSO) signals, and the simulation and observations were compared for each signal.

\section{CCM simulation}

\subsection{Model}

The dynamics module of the MRI-CCM is based on an MJ98 GCM with an eta-ordinate (Shibata et al., 1999). To reproduce the quasi-biennial oscillation (QBO) in the tropical stratosphere, the non-orographic gravity wave drag (GWD) scheme of Hines (1997) is incorporated with an enhanced gravity wave source over the tropics, instead of Rayleigh friction. In addition, the biharmonic horizontal diffusion is weakened only in the middle atmosphere, where the efolding time at the maximum wavenumber 42 is set at $150 \mathrm{~h}$, which is slightly less than the previous value of $180 \mathrm{~h}$ (Shibata and Deushi, 2005a). The chemistry-transport module is taken from the stratospheric one of the MJ98 CTM (Shibata et al., 2005) with HF-related species and reactions incorporated, resulting in 36 long-lived and 15 short-lived species with 80 gas phase reactions, and 35 photodissociations, six heterogeneous reactions on PSCs and three heterogeneous reactions on sulfate aerosols. It should be noted that the chemistry module covers the whole model domain, but does not include detailed processes for tropospheric chemistry. Radiatively active gases providing feedback from chemistry to dynamics are $\mathrm{O}_{3}, \mathrm{CH}_{4}$, and $\mathrm{N}_{2} \mathrm{O}$. MRI-CCM employs the spectral-transform method using triangular truncation at the maximum wavenumber 42 (T42) with a horizontal resolution of 2.8 by 2.8 degrees in longitude-latitude space and has 68 layers (L68) extending from the surface to the mesopause $(\sim 0.01 \mathrm{hPa})$ with $500 \mathrm{~m}$ vertical spacing from 100 to $10 \mathrm{hPa}$. This T42L68 CCM is the same as the one used in the in- tercomparison of CCMs (Eyring et al., 2006) except for the transport scheme of chemical constituents.

MRI-CCM adopts a hybrid semi-Lagrangian transport scheme, which is compatibly solved with the continuity equation and has different forms for horizontal and vertical directions (Shibata et al., 2005). The horizontal form is an ordinary semi-Lagrangian scheme, while the vertical form is equivalent to a mass-conserving flux form in transformed pressure coordinates specified by the vertical velocity. However, the hybrid semi-Lagrangian transport scheme describes only the general formulation without specifying how to calculate abundances at horizontal departure points in the transformed vertical coordinates. The previous scheme (Cubic3) uses a cubic interpolation of neighboring abundances in the horizontal direction and also uses it for overhead column abundances in the vertical direction (Shibata et al., 2005). A new PRM5 scheme is developed for the Cubic3 scheme by improving both vertical and horizontal procedures to simulate better distributions of chemical constituents. The vertical procedure employs the piecewise rational method (PRM) (Xiao and Peng, 2004), and the horizontal procedure uses a quintic interpolation. PRM, which uses an analytically integrable rational function in reconstructing in-cell profiles from cell-averaged values, exhibits better performance for sharp gradient profiles than the piecewise parabolic method (PPM) (Colella and Woodward, 1984) using a parabolic function. This improvement of the transport scheme led to substantial improvements of decreasing ozone positive biases, particularly in the tropical upper troposphere and lower stratosphere (not shown) and of the tape-recorder effect of water vapor in the tropical stratosphere (Mote et al., 1996). Details of the PRM5 scheme and its impacts on the chemistry and dynamics are described by Shibata et al. $(2008)^{1}$.

\subsection{Simulation setup}

A CCM integration is performed under the CCMVal REF1 scenario (Eyring et al., 2005), in which both natural and anthropogenic forcings of SST, sea ice, greenhouse gases, halogens, the 11-year solar cycle, and volcanic aerosols are given daily through interpolation from monthly mean values. The integration period covers November 1979 to December 2004, prior to which a spin-up integration was made for about 10 years using 1970 conditions followed by transient conditions up to November 1979. The general conditions of the REF1 are described in Eyring et al. (2005) and references therein, so specific treatments of the forcings are described here.

The SSTs taken from the UK Met Office Hadley Centre data (HadISST1) (Rayner et al., 2003) are corrected to retain temporal variability even when interpolated from monthly to daily values, similarly to those in the Atmospheric Model

\footnotetext{
${ }^{1}$ Shibata, K., Deushi, M., and Yoshimura, H.: Impacts of the piecewise rational method in advection transport scheme on the distribution of chemical constituents as revealed by a chemistryclimate model, in preparation, 2008.
} 

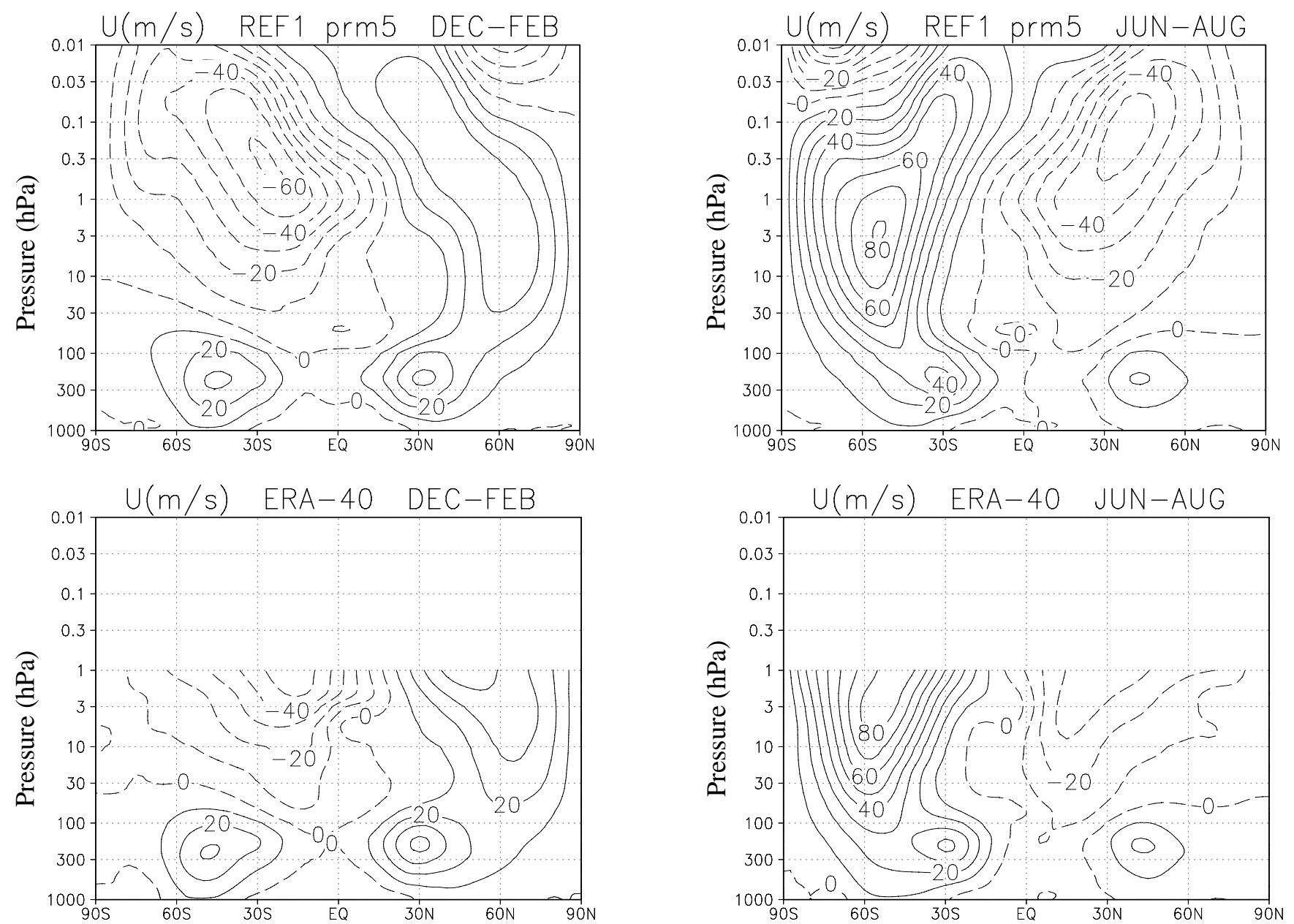

Fig. 1a. Latitude-pressure cross sections of 10-year averages of the seasonal- and zonal-mean zonal wind for the simulation (upper) and ERA40 (lower) during the 1990s (from 1990 to 1999). Left panel is for December to February, and right panel for June to August. Contour intervals are $10 \mathrm{~m} / \mathrm{s}$.

Intercomparison Project (AMIP) II (Taylor et al., 2000). The concentrations of well-mixed GHGs $\left(\mathrm{CO}_{2}, \mathrm{CH}_{4}\right.$, and $\mathrm{N}_{2} \mathrm{O}$ ) based on the Intergovernmental Panel on Climate Change (IPCC) (2001) and those of halogens $\left(\mathrm{CCl}_{4}, \mathrm{CFCl}_{3}\right.$, $\mathrm{CF}_{2} \mathrm{Cl}_{2}, \mathrm{CH}_{3} \mathrm{Cl}, \mathrm{CH}_{3} \mathrm{Br}, \mathrm{CF}_{2} \mathrm{ClBr}$, and $\mathrm{CF}_{3} \mathrm{Br}$ ) derived from the World Meteorological Organization (WMO)/United Nations Environment Programme (UNEP) (2003) and their extended data through 2004 are specified at the surface. In addition, the abundances of $\mathrm{CCl}_{4}, \mathrm{CFCl}_{3}, \mathrm{CF}_{2} \mathrm{Cl}_{2}$, and $\mathrm{CH}_{3} \mathrm{Cl}$ are multiplied by a factor $(\alpha)$ each month, $\alpha=\left(\mathrm{CCl}_{\mathrm{y}}\right) /\left(4\left(\mathrm{CCl}_{4}\right)+3\left(\mathrm{CFCl}_{3}\right)+2\left(\mathrm{CF}_{2} \mathrm{Cl}_{2}\right)+\left(\mathrm{CH}_{3} \mathrm{Cl}\right)\right)$, as in Shibata et al. (2005) to represent the abundance of total chlorine atoms $\left(\mathrm{CCl}_{\mathrm{y}}\right)$ in organic chlorine compounds, which includes other chlorine-bearing species such as $\mathrm{CF}_{3} \mathrm{CCl}_{3}$, $\mathrm{CH}_{3} \mathrm{CCl}_{3}$, and $\mathrm{CHF}_{2} \mathrm{Cl}$ in the real atmosphere. This factor is approximately 1.3 , though it varies with the date. The 11 -year solar cycle is given as irradiance data of $1 \mathrm{~nm}$ spectral resolution, from which a lookup table for photodissociation and solar fluxes of coarser spectral intervals for radiative heating calculation were made as in Sekiyama et al. (2006). After the simulation of the entire period, however, an error was found in a program processing a lookup table for each month, resulting in lookup tables not being varied temporally. Thus, the effect of the 11-year solar cycle is included only through the radiative heating. Volcanic aerosols are taken into account from the zonal-mean stratospheric aerosol optical depth at $0.55 \mu \mathrm{m}$ and effective radius based on Sato et al. (1993) and their extended data (http://data.giss.nasa. gov/modelforce/strataer), and from the surface-area densities (SADs) of sulfate aerosols, similar to those used by Jackman et al. (1996) and updated by D. B. Considine (NASA Langley Research Center) (Eyring et al., 2006). The integration period included two giant volcanic eruptions, El Chichón $\left(7.4^{\circ} \mathrm{N}, 93.2^{\circ} \mathrm{W}\right)$ in March/April 1982 and Mount Pinatubo $\left(15.1^{\circ} \mathrm{N}, 120.4^{\circ} \mathrm{E}\right)$ in June 1991. 

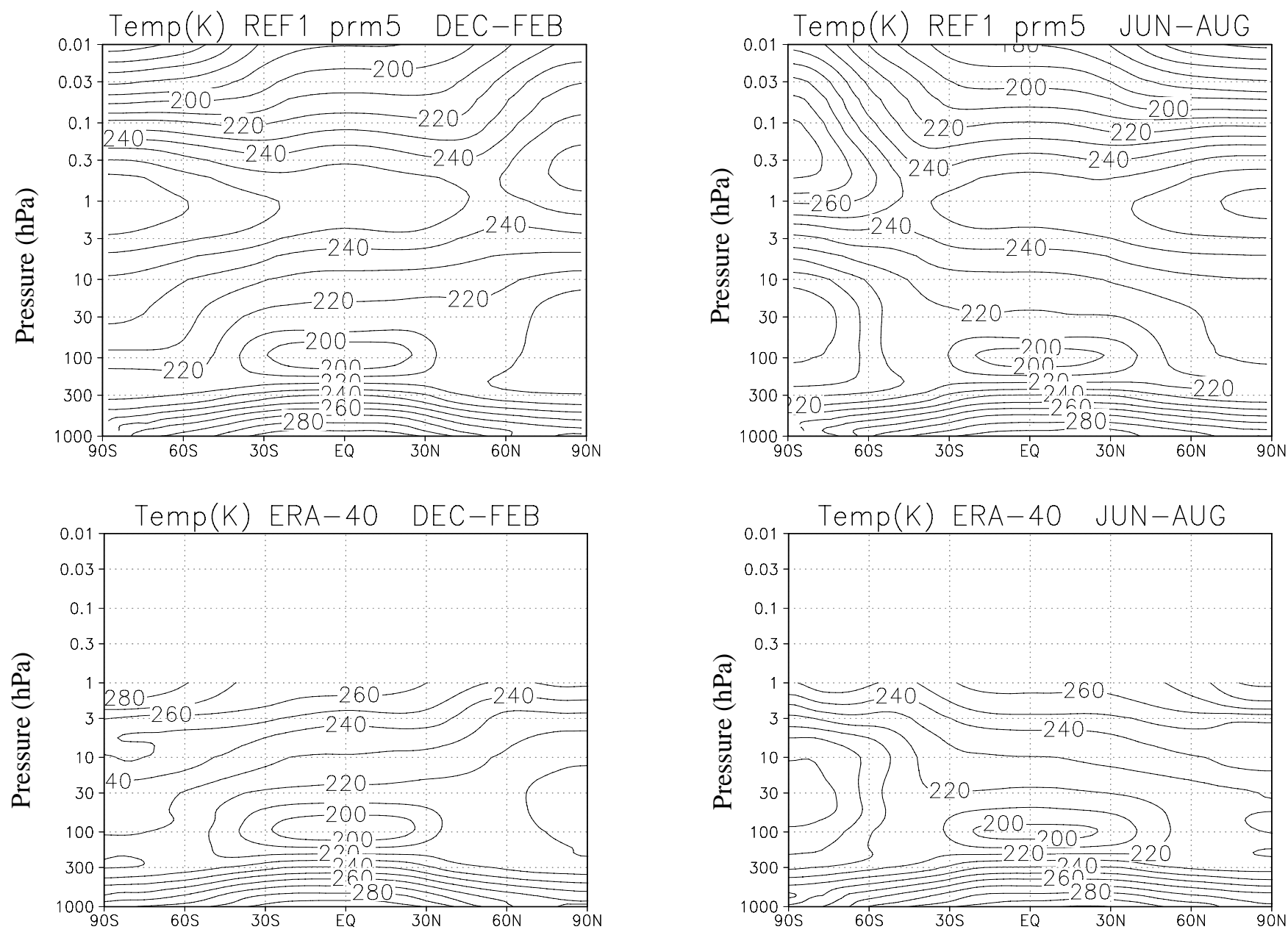

Fig. 1b. Same as in Fig. 1a but for temperature and contour intervals of $10 \mathrm{~K}$.

\section{Climatology}

\subsection{Wind and temperature}

Climatological fields of the simulated seasonal- and zonalmean zonal wind and temperature for the 1990s (10 years from 1990 to 1999) are illustrated in Fig. 1, together with the reanalysis data of ERA-40 (Uppala et al., 2005). Even when ozone and other radiatively active gases are treated interactively, the overall features of observed wind and temperature (e.g. ERA-40; CIRA-86 (Fleming et al., 1990)) are more or less realistically reproduced to similar extents as those in most middle atmospheric GCMs (Pawson et al., 2000). It should be noted that ERA-40 represents modeled data above the upper stratosphere, not necessarily observed data. In the following, climatological fields are described only around the solstice seasons (December to February and June to August) because the degrees of agreement and disagreement with observations are of similar magnitudes between the solstice seasons and equinox seasons (March to May and September to November).
During the northern winter (December to February) the subtropical jet is well reproduced, compared to observations (ERA-40), with respect to the core strength and extent in both hemispheres except for a deeper westerly wind region in the tropical upper troposphere, accompanied by a stronger equatorward extension of the westerly wind. Instead, the northward extension of the subtropical jet is underestimated around $60^{\circ} \mathrm{N}$. In the northern stratosphere, the separation between the subtropical jet and the polar night jet is not well simulated, as revealed from the significantly stronger wind than observed (see the contour of $20 \mathrm{~m} / \mathrm{s}$ ) in the col between the two jets, arising from a cold bias in the polar lower stratosphere. In contrast, the polar upper stratosphere has a warm bias, resulting in a much weaker polar night jet having a slighter equatorward tilt with altitude than observed. This underestimated polar night jet stems from stronger wave activities, which are initiated by stronger GWD and amplified through the wave-mean flow interaction, inducing overestimated poleward ozone transport as described later. The easterly wind in the northern high-latitude mesosphere is due 

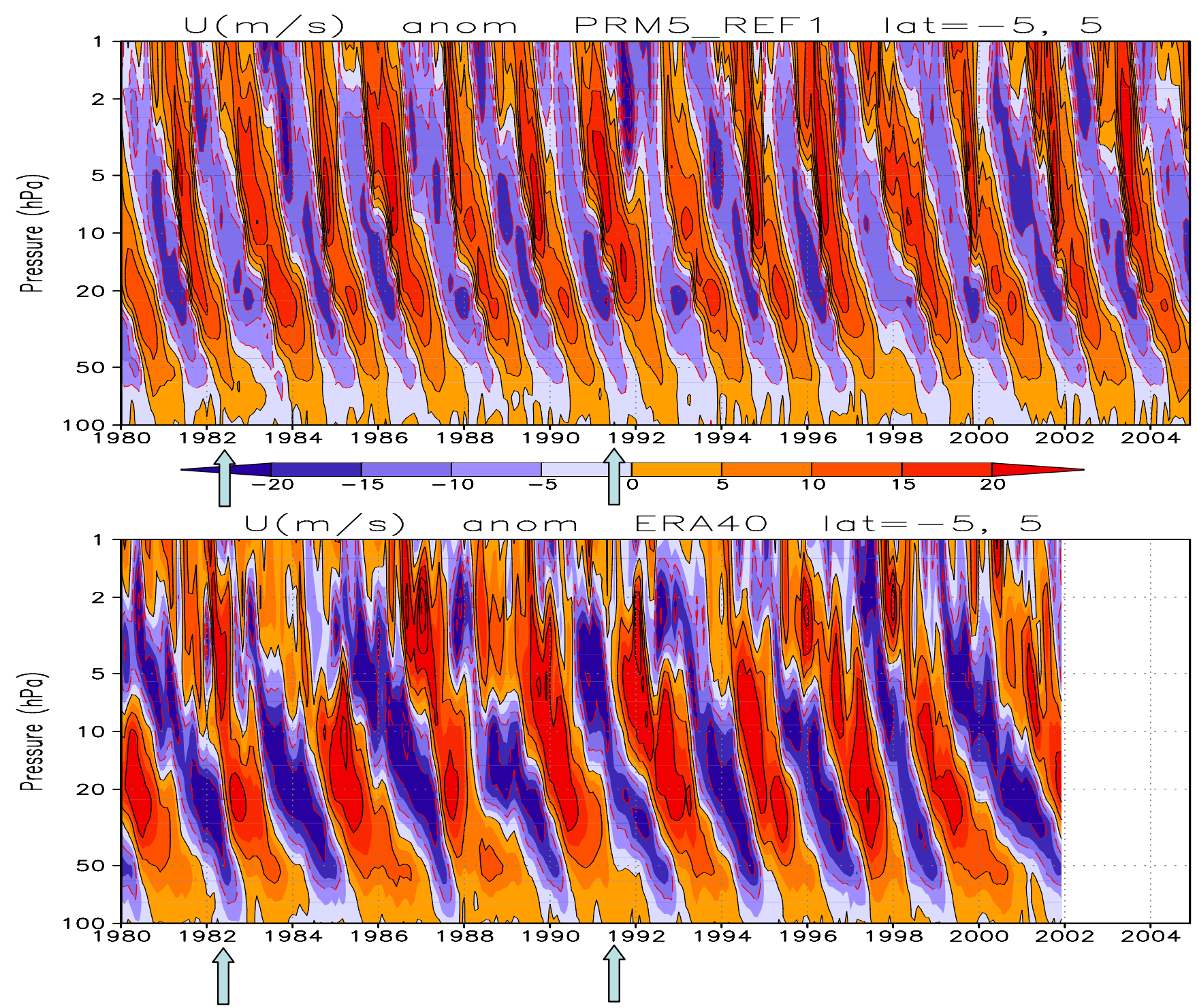

Fig. 2. Evolution of the deseasonalized zonal-mean zonal wind averaged between $5^{\circ} \mathrm{S}$ and $5^{\circ} \mathrm{N}$ from 100 to $1 \mathrm{hPa}$ for the simulation (upper) and observation (ERA-40) (lower). Color shading is the same for both panels, but the contour interval is $5 \mathrm{~m} / \mathrm{s}$ for the simulation and $10 \mathrm{~m} / \mathrm{s}$ for the observation. Arrows represent the eruption dates of El Chichón and Mount Pinatubo.

solely to GWD, yielding a clear equatorward tilt of the polar night jet above the stratopause. Coincident with the poor separation of the two jets in the winter hemisphere, there appears to be an upward extension of the subtropical jet in the summer hemisphere, leading to an upward shift of the zerowind altitude in southern high latitudes.

During the southern winter (June to August), the southern subtropical jet has stronger equatorward and weaker poleward extension, similar to the northern subtropical jet during the northern winter. The polar night jet is more or less realistically reproduced above the middle stratosphere due to the weak wave activities in the Southern Hemisphere, whereas it is overestimated with a cold bias in the lower stratosphere and the separation from the subtropical jet is less clear than in the observations. There appears to be a mesospheric easterly wind in southern high latitudes, similar to that during December to February in northern high latitudes, but the former magnitude is twice $(60 \mathrm{~m} / \mathrm{s})$ as large as the latter, reflecting the difference in the vertical wind profiles below the middle mesosphere. The summer subtropical jet in the Northern Hemisphere is well simulated with the zero-wind line being almost at the observed altitude, in contrast to that during December to February in the Southern Hemisphere. 

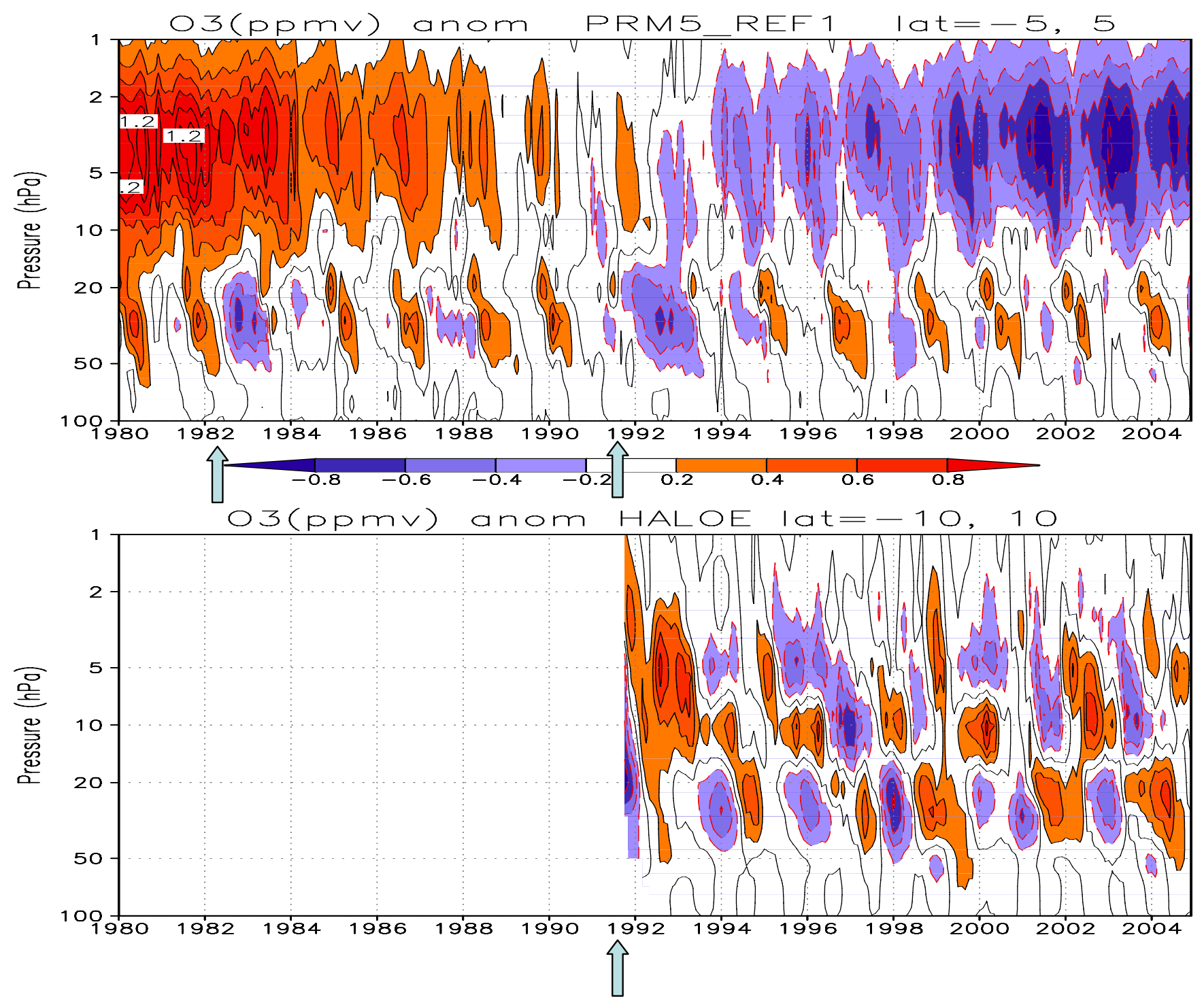

Fig. 3. Same as in Fig. 2 except for the deseasonalized zonal-mean ozone of the simulation (upper) and observation (HALOE) (lower). Contour interval is $0.2 \mathrm{ppmv}$.

\subsection{QBO}

Figures 2 and 3 depict the equatorial $\left(5^{\circ} \mathrm{S}\right.$ to $\left.5^{\circ} \mathrm{N}\right)$ zonalmean zonal wind and ozone deseasonalized by subtracting the long-term monthly means for the simulation and observations. The observed ozone is based on the Halogen Occultation Experiment (HALOE) (Russell et al., 1993). The MRI-CCM of this version also reproduced the QBQ in zonal wind and ozone with its features being very similar to the previous version (Shibata and Deushi, 2005b) simulated under annually repeating forcings, but the period is much shortened (to about 20 months) from the previous value of 31 months through a substantial decrease in ozone positive bias in the tropical lower stratosphere (not shown) arising from the improved transport scheme for chemical constituents.
This shortening of the QBO period can be ascribed to the decrease of the solar heating feedback of ozone because the terrestrial radiation of ozone plays a minor role in the QBO heating budget (Shibata and Deushi, 2005b). The quantitative relationship between the ozone feedback and the QBO period will be described in another paper (Shibata et al., $2008^{1}$ ). Though the simulated QBO amplitude of the zonal wind is smaller than the observations in the stratosphere similar to those in other QBOs by three-dimensional models (e.g. Takahashi, 1999; Butchart et al., 2003; Giorgetta et al., 2006), the simulated QBO still has some observed features: stalling sometimes occurs during the descent of the westward wind; the amplitude of zonal wind peaks at $20 \mathrm{hPa}$; vertical wind shear is stronger in the eastward acceleration than 

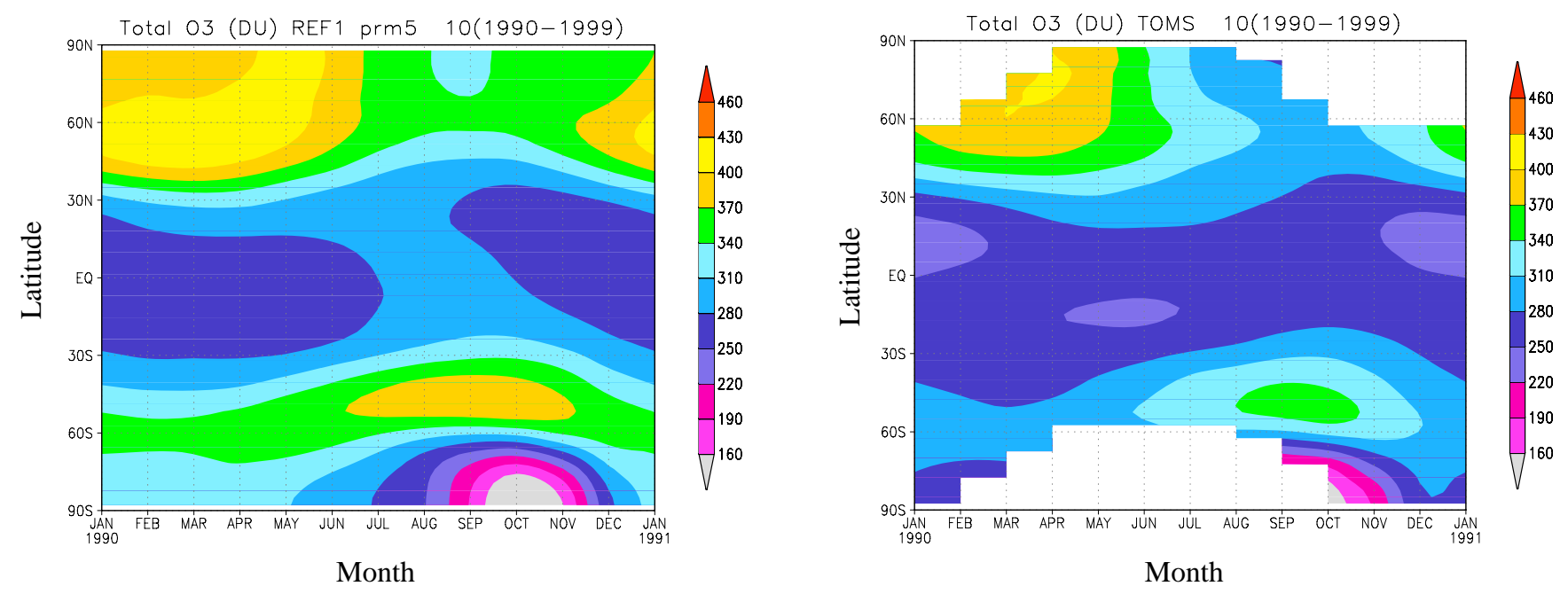

Fig. 4. Month-latitude cross sections of 10-year average of the zonal-mean total ozone (DU) for the simulation (left) and observation (TOMS/SBUV) (right) during the 1990s.

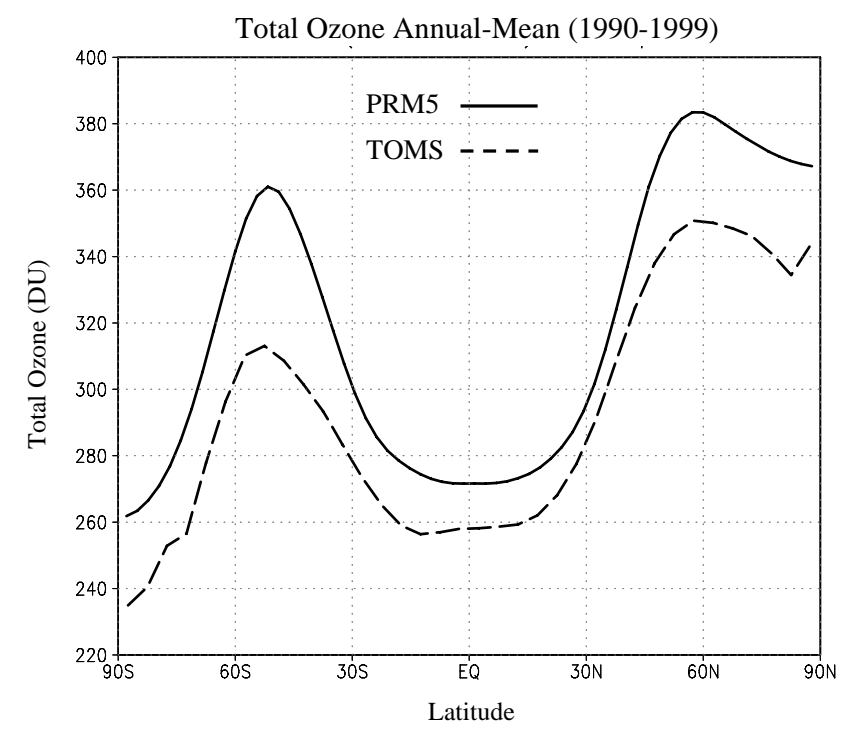

Fig. 5. Latitudinal distributions of the annual- and zonal-mean total ozone (DU) for the simulation (solid line) and observation (TOMS/SBUV) (dashed line) during the 1990s. For both polar regions beyond $60^{\circ}$, annual-mean values are calculated from those days when TOMS measurements were made.

the westward one; and longer duration of the eastward wind than the westward wind below about $50 \mathrm{hPa}$ (e.g. Baldwin et al., 2001; Pascoe et al., 2005). The simulated ozone QBO also captures observed characteristics such as the amplitude peaking at 30 to $40 \mathrm{hPa}$ and diminishing rapidly below $50 \mathrm{hPa}$ (e.g. Randel and Wu, 1996; Logan et al., 2003). The lag correlation between ozone and zonal wind reveals that the phase of the ozone QBO precedes that of the zonal wind QBO by about a quarter cycle below $20 \mathrm{hPa}$ (not shown) as it does in observations (Hasebe, 1994) even though the simulated QBO period is much shorter than the observed one.

In the upper stratosphere, however, the simulated QBO amplitudes of zonal wind and ozone are much larger than observations, particularly above $5 \mathrm{hPa}$ as in the previous version (Shibata and Deushi, 2005b). In contrast, the ozone QBO at about $10 \mathrm{hPa}$ is underestimated in the simulation, and so the vertical structure of double peaks with alternating sign was not well reproduced in the simulation. In addition, a decreasing trend is evident in the simulated ozone, while no such trend can be seen in zonal wind of the simulation and the observations. This decreasing trend in the simulated ozone is statistically significant below the middle stratosphere as well, as will be described later.

It should be noted that the simulated QBO phase is very different from the observed QBO phase due to the period differences as can readily be seen from Figs. 2 and 8. Likewise, the QBO phase relation with the seasonal cycle is very different from observations. Thus, the atmospheric and chemistry responses to the imposed forcings may differ from observed ones not only in the tropics but also in the extratropics through the mean meridional circulation (e.g. Plumb and Bell, 1982) associated with the QBO, even if the various observed forcings are used.

\subsection{Ozone}

The simulated and observed climatological seasonal cycle of the zonal-mean total ozone for the 1990s is depicted as a function of months in Fig. 4. The observed ozone is taken from satellite measurements by the total ozone mapping spectrometer (TOMS) and solar backscattered ultraviolet (SBUV), i.e. TOMS/SBUV merged total and profile ozone datasets based on the version 8 retrieval algorithm 

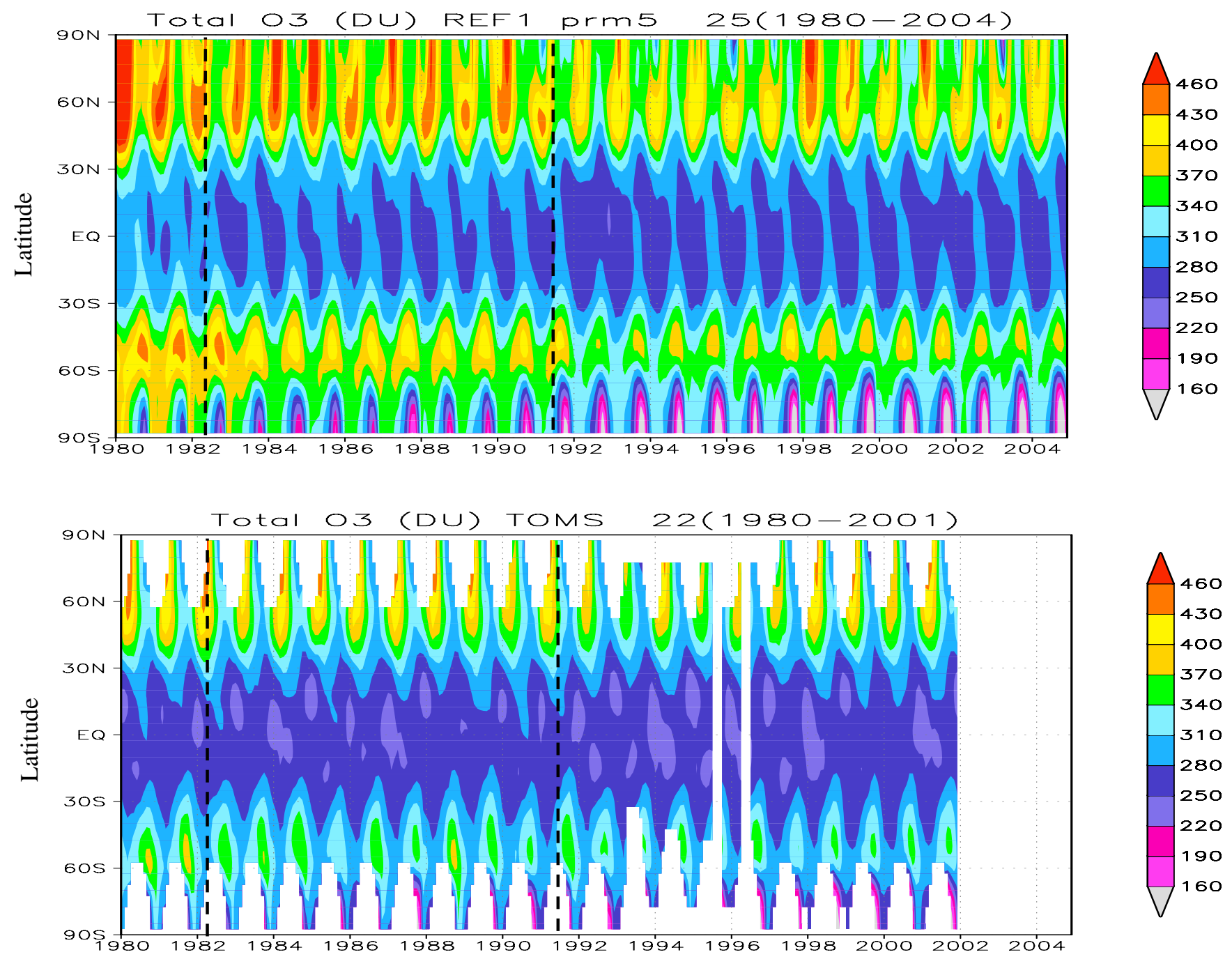

Fig. 6. Evolutions of zonal-mean total ozone latitudinal distribution for the simulation (upper) and observation (TOMS) (lower). Dotted lines indicate the eruption dates of El Chichón and Mount Pinatubo.

(http://code916.gsfc.nasa.gov/Data_services/merged). The model reproduced the overall seasonal evolution of the total ozone but exhibited positive biases everywhere. The relatively high positive biases in northern high latitudes and in southern mid-latitudes from winter to spring in each hemisphere stem from the overestimated poleward ozone transport. As annual mean values, the positive biases are slightly less than $20 \mathrm{DU}$ in the tropics and reach 20 to $40 \mathrm{DU}$ in the extratropics of both hemispheres as illustrated in the 1990s' ozone (Fig. 5). Interannual variations of the simulated annual-mean total ozone are about 6 DU in the tropics, $10 \mathrm{DU}$ in the northern latitudes, and 16 DU in the southern high latitudes, while the corresponding observed values are 2,4 , and 3 DU. Note that the observed values in high latitudes are calculated from those days when TOMS measurements were made. The simulated extratropical total ozone in the Northern Hemisphere peaks in April/May, about one month later than observations, because the simulated transition in dynamics from winter to spring, i.e. from westerly to easterly winds, is retarded by about one month in the stratosphere. In contrast, the minimum total ozone appears in September as in observations. In the tropics, the minimum axis of the simulated total ozone crosses the equator from north to south in mid-winter and again from south to north in mid-summer, unlike the observed months around the spring equinox and autumnal equinox. In the southern extratropics, a maximum total ozone appears around $50^{\circ} \mathrm{S}$ from July to November, and the ozone hole occurs inside the strong and persistent polar vortex in October/November, about one month later than observations. This is due to a much deeper simulated polar-vortex than observed that retards the seasonal change from winter to spring by about one month as in the Northern Hemisphere. 

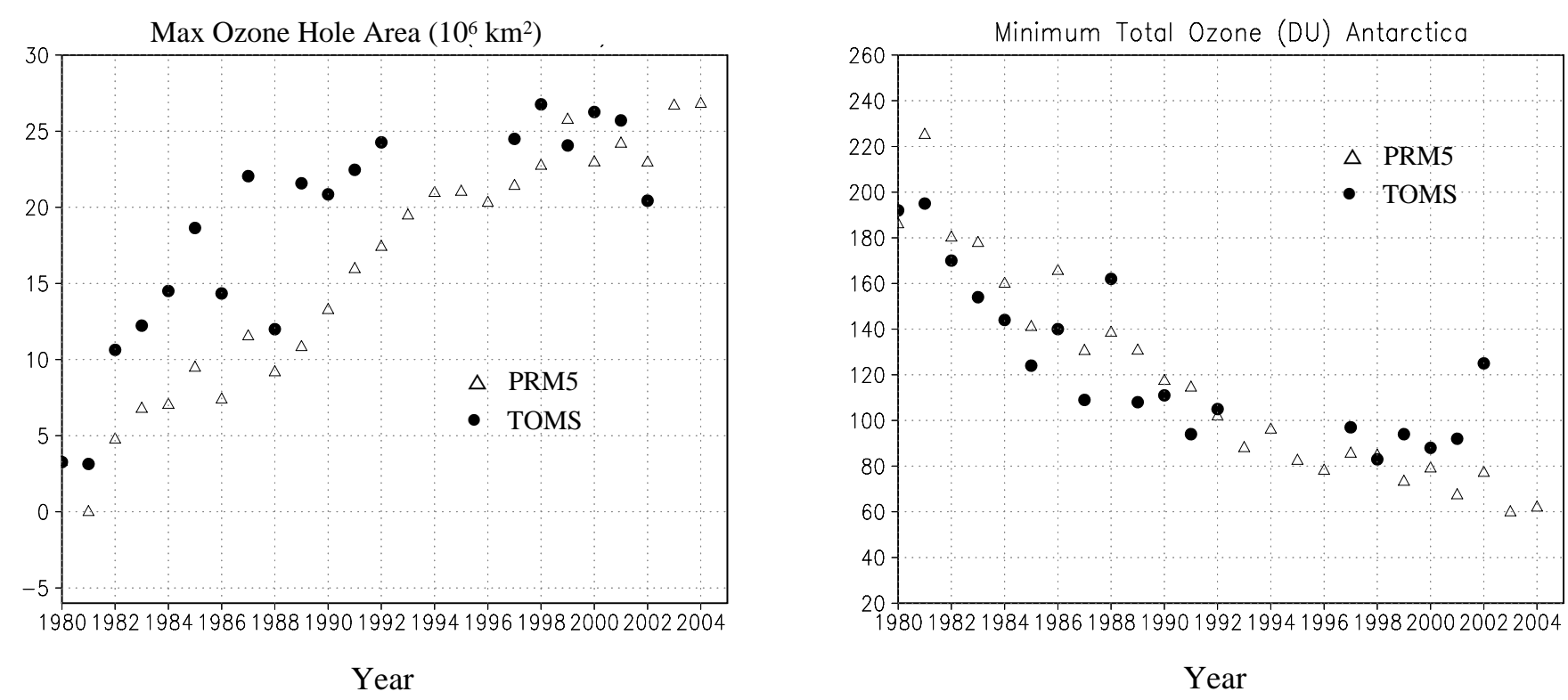

Fig. 7. Evolutions of the annual maximum area of the Antarctic ozone hole ( $<220 \mathrm{DU})$ in units of $10^{6} \mathrm{~km}^{2}$ (left) and the annual minimum of total ozone in DU (right). Triangles represent simulated data, and filled circles represent observed data (TOMS/SBUV).

The time evolution of the total ozone for the entire period (1980 to 2004) is displayed in Fig. 6, together with the observed (TOMS/SBUV) total ozone for 1980 to 2001. The model simulates larger interannual variations in the northern high latitudes than in southern high latitudes, similar to the observations. The simulated ozone hole area increased year by year beginning in the early 1980s and eventually became saturated from the late 1990s. Quantitatively, however, the model significantly underestimates the maximum ozone hole area until the late 1990s, while the simulated minimum total ozone quantitatively coincides well with the observation, as depicted in Fig. 7. It is evident that the simulated total ozone exhibits prominent decreasing trends in the extratropics of both hemispheres and in the tropics, whereas the observation has no decreasing trend in the tropics (e.g. Fioletov et al., 2002). The details of the trend are described below using a multiple linear regression analysis.

\section{Specific signals in regression analysis}

Multiple linear regression analysis is used to isolate specific signals from the zonal-mean anomalies in temperature, zonal wind, and ozone data for the simulation and observations (e.g. Randel and Cobb, 1994; Bodeker et al., 2001). Reference (explanatory) variables are the mean value, the linear trend, the QBOs at 20 and $50 \mathrm{hPa}$, volcanic aerosols of $\mathrm{El}$ Chichón and Mount Pinatubo, ENSO, and the 11-year solar cycles. Thus the regression model for ozone is

$$
\begin{aligned}
\mathrm{O} 3(t)= & A+B \times t+C \times \mathrm{QBO}^{50 \mathrm{hPa}}(t)+D \times \mathrm{QBO}^{20 \mathrm{hPa}}(t) \\
& +E \times \text { El Chichón }(t-\alpha)+F \times \text { Pinatubo }(t-\beta)
\end{aligned}
$$

$$
\begin{aligned}
& +G \times \operatorname{ENSO}(t)+H \times \text { Solar Flux }(t) \\
& +\operatorname{Residual}(t),
\end{aligned}
$$

and likewise for temperature, where $\alpha$ and (are time lags (in months) of less than or equal to 12 . Coefficients A through $\mathrm{G}$ (referred to as signals henceforth) are expanded by annual, semiannual, and triannual cycles to explain seasonality.

$$
\begin{aligned}
A= & a_{0}+a_{1} \cos (\omega t)+b_{1} \sin (\omega t)+a_{2} \cos (2 \omega t) \\
& +b_{2} \sin (2 \omega t)+a_{3} \cos (3 \omega t)+b_{3} \sin (3 \omega t), \\
\omega= & 2 \pi /(12 \text { months }) .
\end{aligned}
$$

The QBO reference terms are taken from the zonal-mean zonal winds over the equator at 20 and $50 \mathrm{hPa}$ (henceforth referred to as QBO20 and QBO50). It should be noted that QBO20 and QBO50 are not orthogonal both in the simulation and ERA-40, being different from the QBO empirical orthogonal functions (EOFs) 1 and 2 (e.g. Crooks and Gray, 2005; Stolarski et al., 2006). However, QBO20 and QBO50 are approximately a quarter-cycle apart as depicted in Fig. 8, indicating that they can be treated as independent reference variables. The volcanic reference terms are the global-mean optical depths at $0.55 \mu \mathrm{m}$ with time lags $\alpha$ and $\beta$ to represent delayed responses of ozone and temperature. The time lags $\alpha$ and $\beta$ are calculated that the correlation between the regressed data and target data is largest at each point for $\alpha \leq 12$ and $\beta \leq 12$. The ENSO reference term is the Southern Oscillation Index (SOI), and the solar reference term is the $10.7 \mathrm{~cm}$ radio flux (F10.7) in solar units $\left(10^{-22} \mathrm{~W} \mathrm{~m}^{-2} \mathrm{~Hz}^{-1}\right)$.

The coefficients in the regression model are calculated with the least-squares method against deseasonalized monthly-mean data, which are set to zero for missing data 

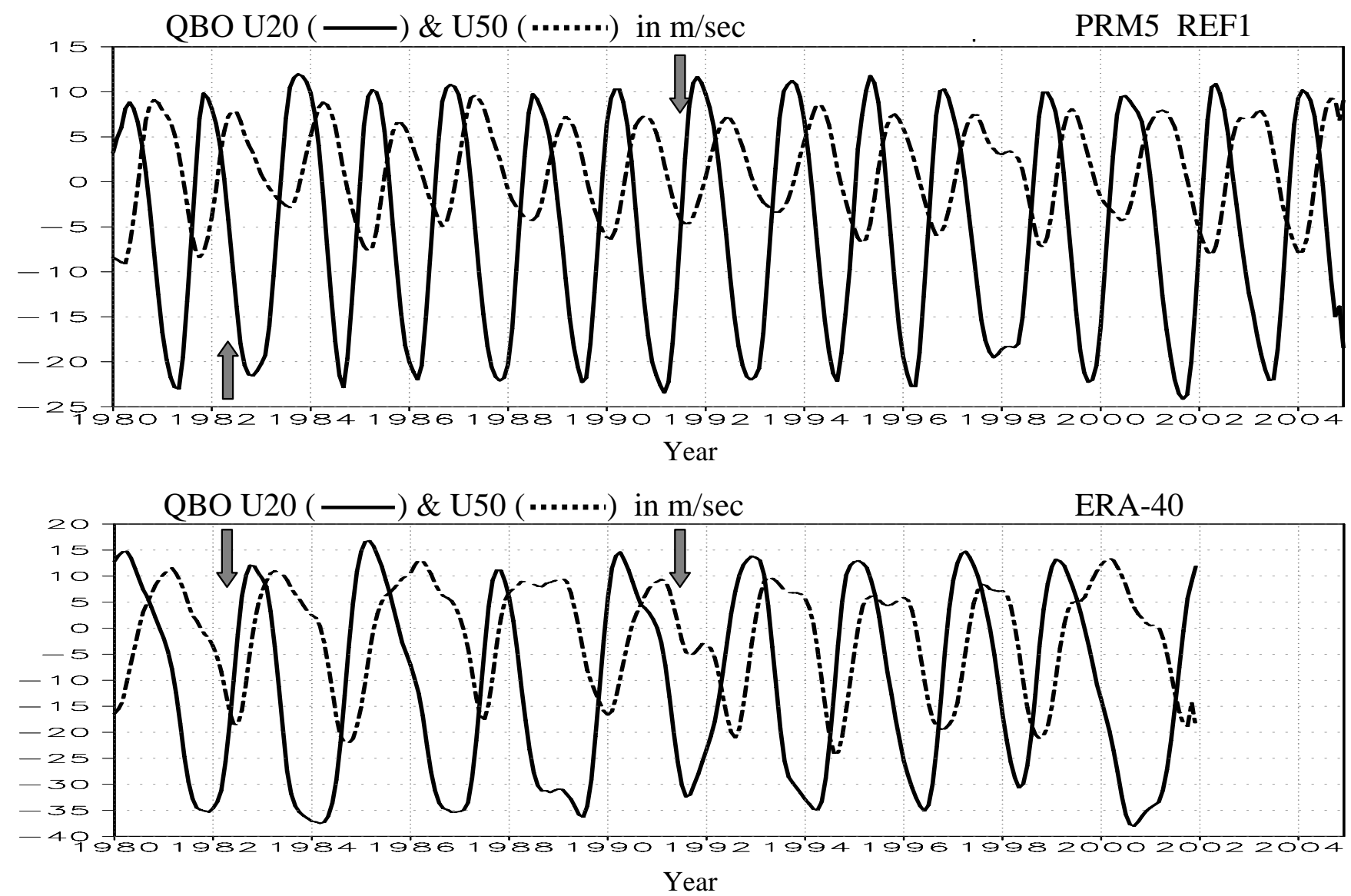

Fig. 8. Evolution of the zonal-mean zonal winds $(\mathrm{m} / \mathrm{s})$ at $20 \mathrm{hPa}$ (solid curve) and $50 \mathrm{hPa}$ (dashed curve) over the equator for the simulation (upper) and observation (ERA-40) (lower). Arrows represent the eruption dates of El Chichón and Mount Pinatubo.

periods in observations of ozone. The residual term, which regulates the performance of the fitting, is found to be small enough to assure the validity of the current regression model. For example, the proportion of zonal mean temperature, i.e. the ratio of the variances of the regressed data and target data, exceeds 0.55 in the stratosphere approximately between $40^{\circ} \mathrm{S}$ and $50^{\circ} \mathrm{N}$ for the simulation and between $40^{\circ} \mathrm{S}$ and $40^{\circ} \mathrm{N}$ for ERA-40. Since the square root of the ratio is the correlation coefficient between the regression data and target data, a ratio of 0.55 corresponds to 0.74 for the correlation coefficient. In addition, the regression model can explain the variance for ozone better than the variance for temperature in the stratosphere both for the simulation and observations (SBUV) as in Randel and Cobb (1994).

The results of the regression models require some attention. Sensitivity tests on the trend term (Bojkov et al., 1990; SPARC, 1998) demonstrated that the trend term is relatively insensitive, i.e. about $10 \%$ changes, to the inclusion or exclusion of the QBO, solar and other terms, as long as the time series is sufficiently longer than the 11-year solar cycle (SPARC, 1998). The trend standard errors, however, could be sensitive. The time series of the current analysis covers approximately two 11-year solar cycles for the CCM simulation ( 25 years) and ERA-40 (22 years), so that the trend signal is expected to be valid for these two data sets. The ozone trend signal is also roughly valid in the tropics mid-latitudes and between $60^{\circ} \mathrm{S}$ and $60^{\circ} \mathrm{N}$, where data of over 20 years is used. However, the trend signal derived in this study differs from those based on different regression models, as will be described later, because the multiple linear regression analysis does not necessarily yield unique signals and could result in different signals for different reference sets because some of the reference variables are not orthogonal to each other.

\subsection{Trend}

Figure 9 displays the linear trend (K/decade) of the annualand zonal-mean temperature from $60^{\circ} \mathrm{S}$ to $60^{\circ} \mathrm{N}$ for the simulation and observation (ERA-40). The model reproduces the statistically significant cooling trend throughout midand low-latitudes in the stratosphere and mesosphere with a maximum cooling exceeding $2.5 \mathrm{~K} / \mathrm{dec}$ ade at the stratopause from $40^{\circ} \mathrm{S}$ to $30^{\circ} \mathrm{N}$. Statistically significant cooling can also be seen in the southern polar region below $10 \mathrm{hPa}$, 

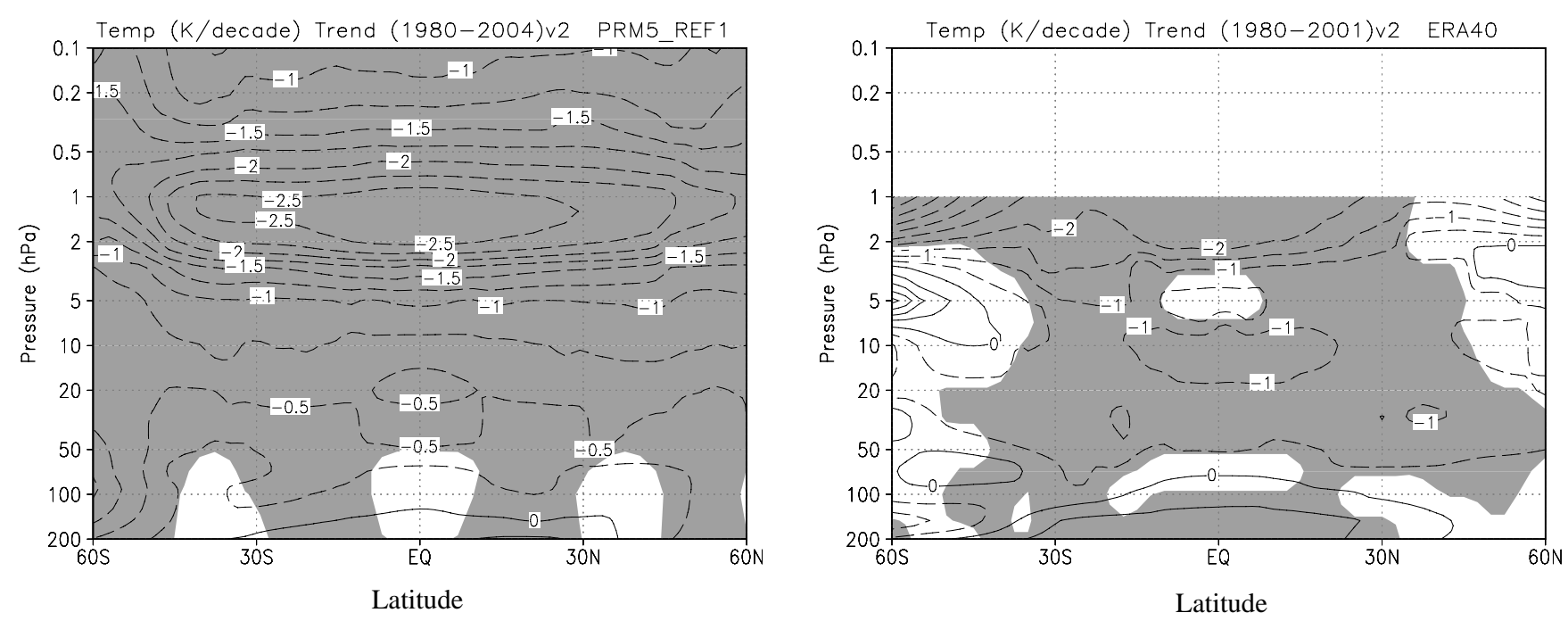

Fig. 9. Latitude-pressure cross sections of the temperature linear trend (K/decade) from 200 to $0.1 \mathrm{hPa}$ between $60^{\circ} \mathrm{S}$ and $60^{\circ} \mathrm{N}$ for the simulation (left) and observation (ERA-40) (right). Contour interval is $0.25 \mathrm{~K} /$ decade for the simulation and $0.5 \mathrm{~K} /$ decade for the observation. Shading denotes the area of the linear trend different from zero at the $95 \%$ confidence level (t-test).
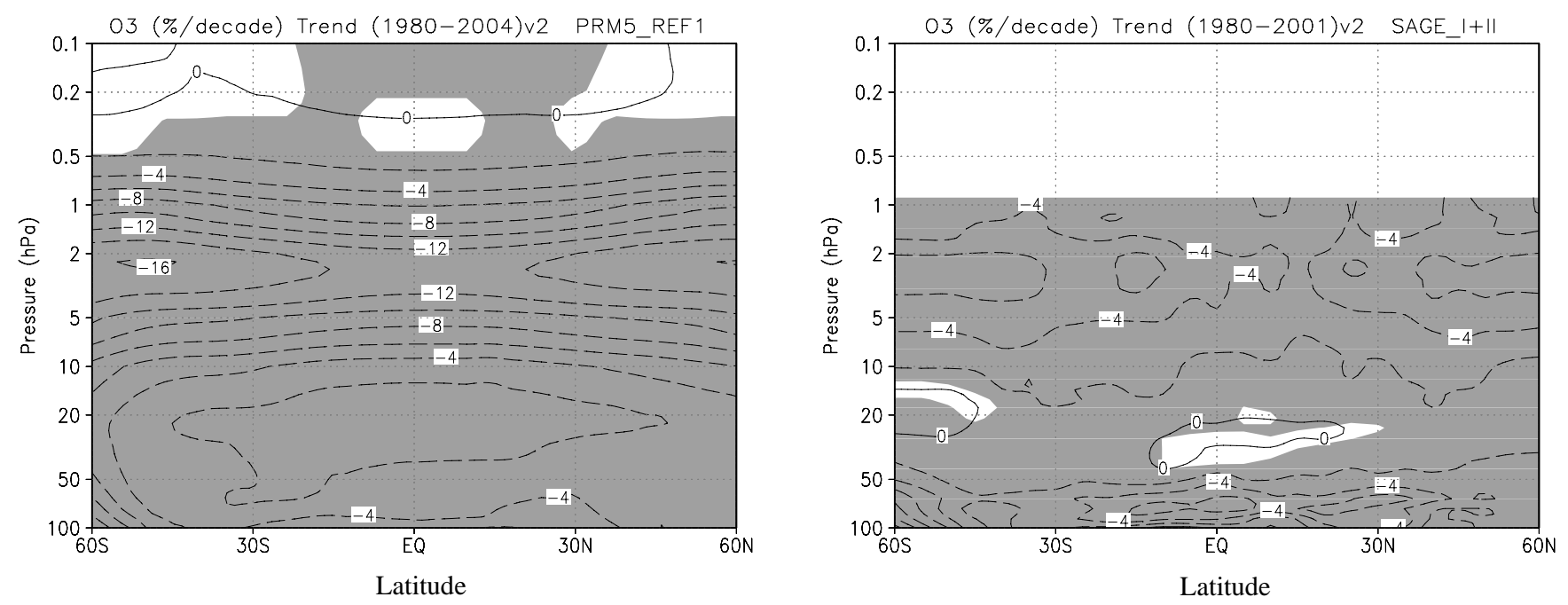

Fig. 10. Same as in Fig. 8 except that ozone is in \%/decade with a contour interval of $2 \% /$ decade and the observation is SAGE I/II (Randel and WU, 2007).

particularly in the lower stratosphere. In contrast, ERA-40 indicates that the statistically significant cooling trend occupies a narrower meridional extent, approximately from $40^{\circ} \mathrm{S}$ to $40^{\circ} \mathrm{N}$ in the upper stratosphere, and extends downward and poleward to about $60^{\circ} \mathrm{N}$ in the northern lower stratosphere. The maximum cooling at the stratopause is approximately $2.5 \mathrm{~K} / \mathrm{decade}$, very similar to the simulation. However, some satellite observations reveal a somewhat different trend pattern, particularly poleward of $40^{\circ}$ of both hemispheres, although the maximum cooling at the stratopause is of the same magnitude. The combined datasets of Stratospheric Sounding Unit (SSU)/Microwave Sounding Unit
(MSU) indicate statistically significant cooling above $40 \mathrm{~km}$ $\left(\sim 3 \mathrm{hPa}\right.$ ) extending from $70^{\circ} \mathrm{S}$ to $65^{\circ} \mathrm{N}$ in the upper stratosphere with interhemispheric symmetry and another statistically significant cooling in the extratropics $\left(20^{\circ}\right.$ to $60^{\circ} \mathrm{N}$ and $20^{\circ}$ to $60^{\circ} \mathrm{S}$ ) of about 0.4 to $0.8 \mathrm{~K} /$ decade in the lower stratosphere below a relative minimum cooling in the middle stratosphere (around 30 to $35 \mathrm{~km}$ ) (WMO/UNEP, 2003).

Figure 10 depicts the linear trend (\%/decade) of the annual- and zonal-mean ozone from $60^{\circ} \mathrm{S}$ to $60^{\circ} \mathrm{N}$ for the simulation and observation, the latter of which is taken from reconstructed data from the Stratospheric Aerosol and Gas Experiment (SAGE I and II) (McCormick et al., 1989) data 

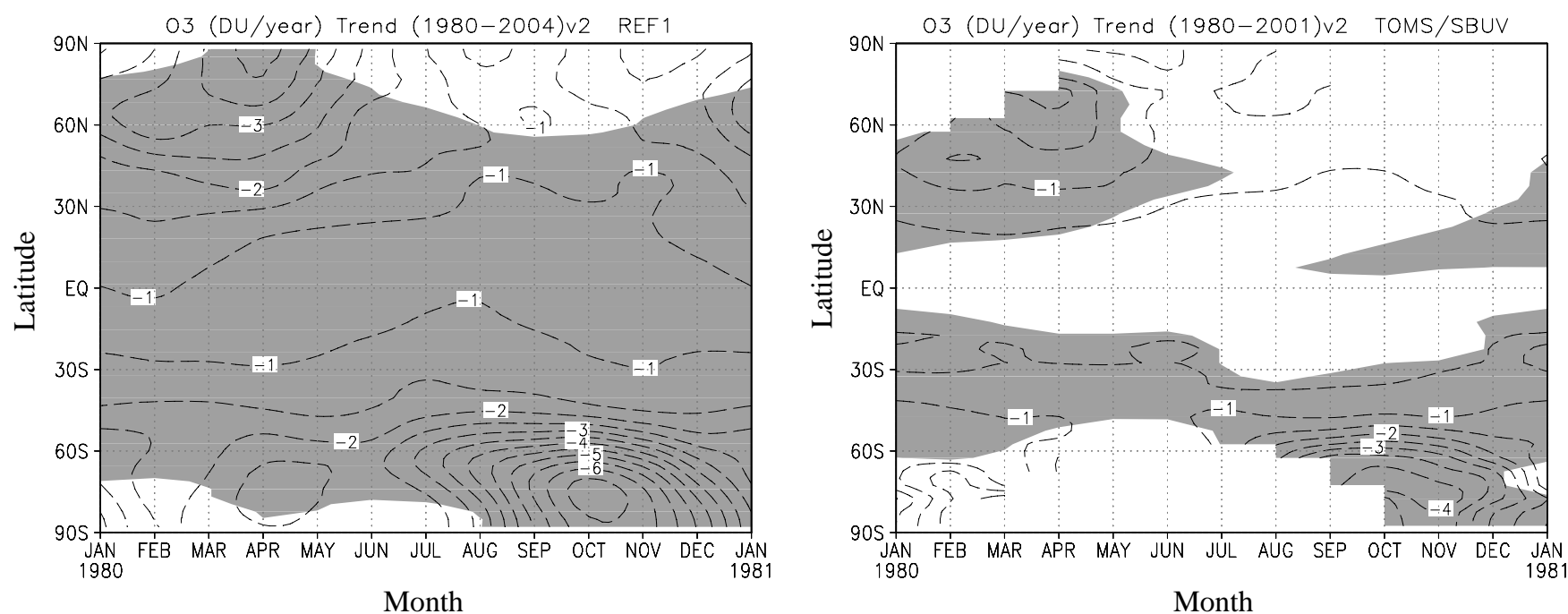

Fig. 11. Month-latitude cross sections of the total ozone trend (DU/year) between $90^{\circ} \mathrm{S}$ and $90^{\circ} \mathrm{N}$ for the simulation (left) and observation (TOMS/SBUV) (right). Contour interval is 0.5 DU/year, and shading denotes the area of the trend different from zero at the $95 \%$ confidence level (t-test).

with a multiple linear regression model using the decadal trend, solar cycle, and EOF1 and 2 of the QBO (Randel and $\mathrm{Wu}, 2007)$ as reference variables. The simulation reproduced SAGE I/II observed features of a latitudinally symmetric ozone decrease trend with maxima in the extratropical upper stratosphere $(2$ to $5 \mathrm{hPa})$, a second maximum in the tropical lower stratosphere (50 to $100 \mathrm{hPa}$ ), and a minimum (or positive) in between $(\sim 25 \mathrm{hPa})$ in the tropics (e.g. WMO/UNEP, 2003; Newchurch et al., 2003; Randel and Wu, 2007), although the observed trends from SAGE I/II do not necessarily quantitatively agree with each other depending on analysis periods and methods. The simulated maxima in the extratropical upper stratosphere of -14 to $-16 \% /$ decade are twice as large as the observed values of -6 to $-8 \% /$ decade. In contrast, the simulated second maximum of $-4 \% /$ decade in the tropics is two-thirds of the observed trend of $-6 \% /$ decade. These two observed maximum amplitudes in Fig. 10 are analyzed as larger values of -12 and $-8 \%$ /decade for 1979 to 2005 in Randel and Wu (2007). This discrepancy comes from the difference in the reference variables of the multiple linear regression models, as stated before.

Figure 11 plots the linear trend (DU/year) of the zonalmean total ozone as a function of month from $90^{\circ} \mathrm{S}$ to $90^{\circ} \mathrm{N}$ for the simulation and observation (TOMS/SBUV). The simulation captured the observed major characteristics of the severest total ozone depletion associated with the ozone hole in southern high latitudes during late winter (August) to early summer (December), and the second maximum ozone decrease in northern high latitudes during early spring, March to April, although the simulation somewhat overestimated the absolute values. In contrast, the model calculated a persistent total ozone decrease in the tropics throughout the year, similar to a small but significant negative annual mean trend of a CTM simulation (Stolarski et al., 2006), in conspicuous contrast to the observed (TOMS/SBUV) near-zero value. However, as pointed out by Randel and Wu (2007), the trend based on TOMS/SBUV data might indicate the tropospheric positive ozone trend canceling the stratospheric negative trend because the vertically integrated column ozone from SAGE I/II does exhibit a significant decrease of $8 \mathrm{DU}$ from 1979 to 2005 in the tropics. If this is true, the simulated weak but significant negative trend in the tropics well reproduced the observed stratospheric ozone decrease because the model did not include detailed tropospheric chemistry.

\subsection{QBO signals}

The meridional structure of the simulated annual mean QBO wind signals are shown together with the observation in Fig. 12. The simulated QBO20 wind signal has a three-cell vertical structure of alternating sign, extending to the mesosphere with a positive cell from 50 to $10 \mathrm{hPa}$, a negative cell above $0.8 \mathrm{hPa}$, and the other positive cell above in the mesosphere. Though the vertical extent of the positive cell centered at $20 \mathrm{hPa}$ is slightly smaller, the simulated signal in the stratosphere agrees well with the observed stratospheric twocell structure, the vertical profile of which is very similar to the QBO weight profile yielding the best fit to the total ozone QBO (Randel et al., 1995). The signal peaks over the equator and is latitudinally symmetric with half-widths of about 20 degrees in the stratosphere. The QBO50 zonal wind signal has a similar but vertically phase-shifted three-cell structure with a negative cell from 20 to $2 \mathrm{hPa}$, and positive cells below and above this range. It is qualitatively in good agreement with the observed three-cell signal in the stratosphere, 

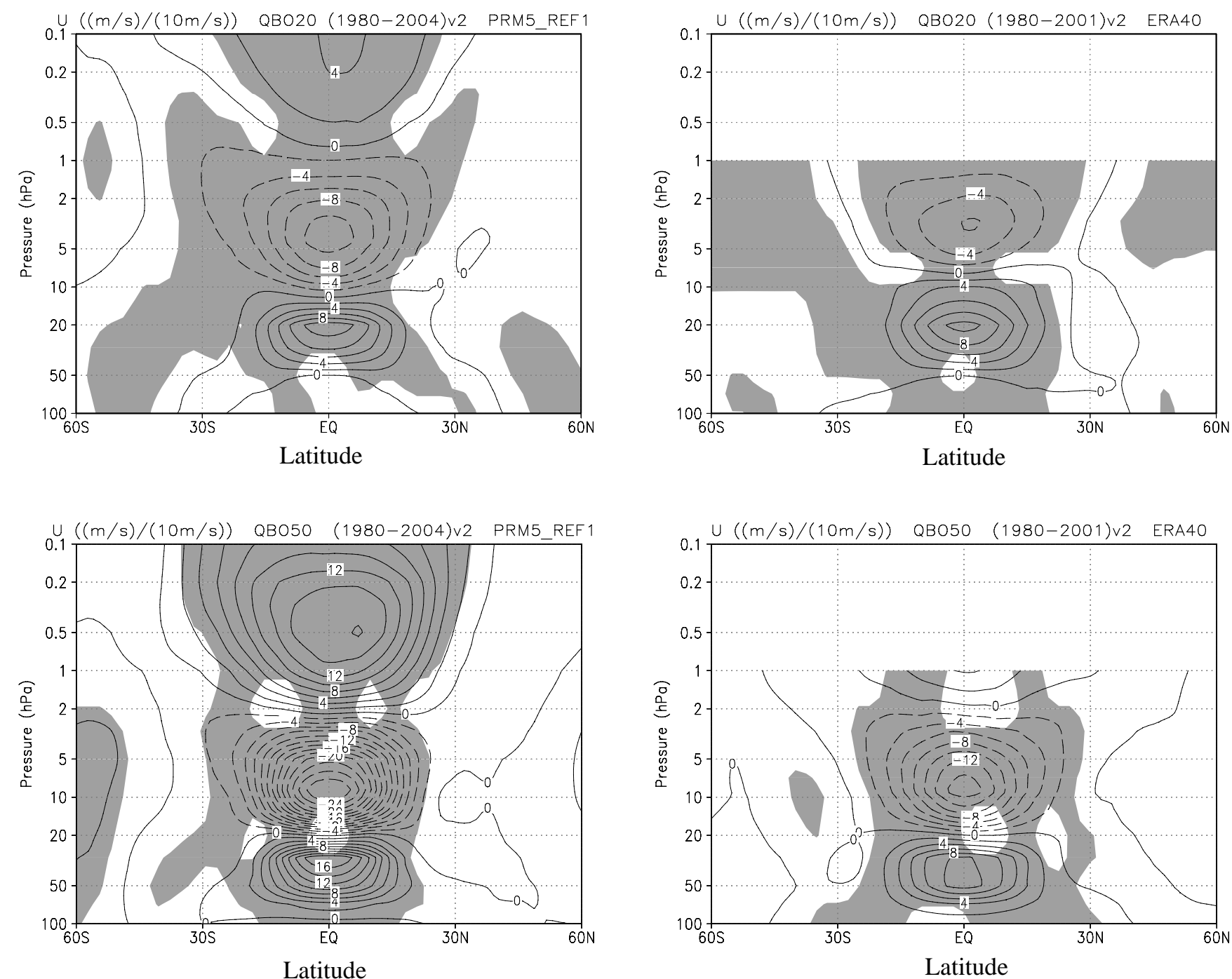

Fig. 12. Latitude-pressure cross sections of the QBO20 (upper) and QBO50 (lower) zonal winds in $\mathrm{m} / \mathrm{s}$ per $10 \mathrm{~m} / \mathrm{s}$ of the QBO winds at 20 and $50 \mathrm{hPa}$ between $60^{\circ} \mathrm{S}$ and $60^{\circ} \mathrm{N}$ for the simulation (left) and observation (ERA-40) (right). Contour interval is $2(\mathrm{~m} / \mathrm{s}) /(10 \mathrm{~m} / \mathrm{s})$, and shading denotes the $95 \%$ confidence level (t-test).

though the observed signal shows only the peripheral part of the uppermost positive cell between 2 and $1 \mathrm{hPa}$. It should be noted that the peak values of the QBO50 signal are approximately twice as large as those of the QBO20 signal for the simulation, and the QBO50 reference amplitude is about half of the QBO20 reference amplitude (Fig. 8). As a result, the product of the signal and reference is of similar magnitude in the multiple linear regression model (Eq. 1). Also, the ratio of the reference amplitudes (QBO20/QBO50) in the observations is about two, and the ratio of the signal amplitude is about 0.8 for the positive cells and 0.4 for the negative cells. Thus, the products of the signal and reference are approximately the same magnitude for the negative cells but are much larger for QBO20 than for QBO50.
The QBO signals of QBO20 and QBO50 exhibit a wider latitudinal extent of about \pm 30 degrees in the mesosphere than in the stratosphere (about \pm 20 degrees), coinciding with satellite measurements by the high-resolution Doppler imager (HRDI) on the Upper Atmosphere Research Satellite (UARS) (Burrage et al., 1996). There is also a slight hint of this above $2 \mathrm{hPa}$ in the QBO50 zonal wind signal (Fig. 12) of ERA-40 available up to $1 \mathrm{hPa}$. A similar feature is just visible in the analysis using a higher ERA-40 dataset up to $0.1 \mathrm{hPa}$ (Crooks and Gray, 2005), in which the QBO references are the QBO EOF 1 and 2. Although the QBO amplitude in the mesosphere is barely discernible and diminishing monotonically with altitude in the ERA-40 (Baldwin and Gray, 2005; Pascoe et al., 2005), the mesospheric QBO distinctly appeared in MRI-CCM and is analyzed by 

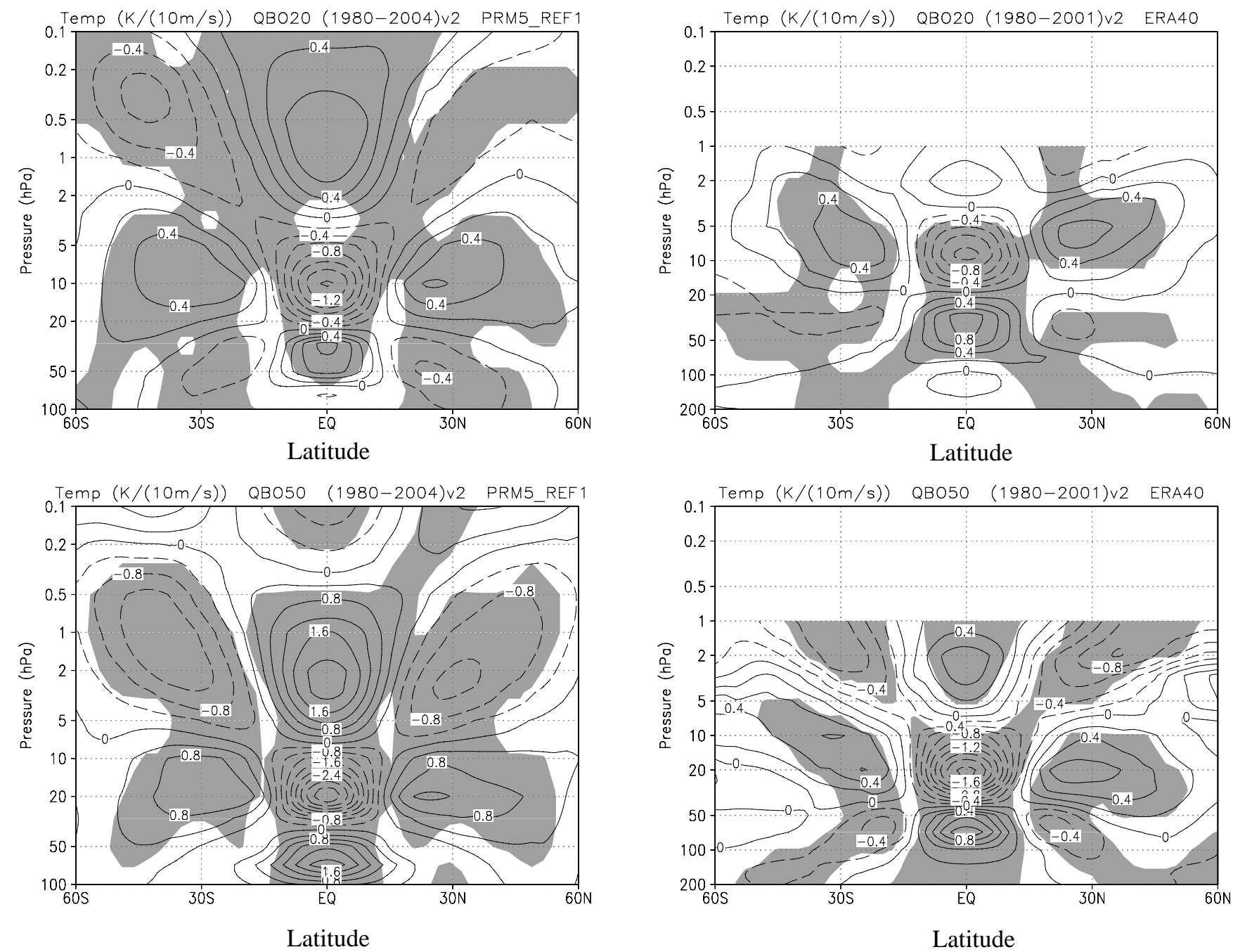

Fig. 13. Same as in Fig. 12 except for temperature in $\mathrm{K} /(10 \mathrm{~m} / \mathrm{s})$. Contour interval is $0.2 \mathrm{~K} /(10 \mathrm{~m} / \mathrm{s})$ for $\mathrm{QBO} 20$ and $\mathrm{QBO} 0$, but $0.4 \mathrm{~K} /(10 \mathrm{~m} / \mathrm{s})$ for the $\mathrm{QBO} 50$ of the model.

multiple linear regression. A similarly clear mesospheric QBO is simulated in a high-vertical-resolution version of the MAECHAM5 GCM (Giorgetta et al., 2006).

Figure 13 depicts the simulated and observed annual-mean QBO20 and QBO50 temperature signals, both of which peak over the equator with latitudinal symmetry (Crooks and Gray, 2005 ) as the wind signals in Fig. 12. In the equatorial region, their latitudinal extents are narrower than those of the wind signals, with half-widths of about 15 degrees in the stratosphere and 20 degrees in the mesosphere. The QBO20 temperature signals have a three-cell structure (Crooks and Gray, 2005) very similar to that of the QBO50 wind signals, while the QBO50 temperature signal has a four-cell structure with a positive cell from below 100 to $30 \mathrm{hPa}$, a negative cell to $7 \mathrm{hPa}$, the other positive cell to $0.3 \mathrm{hPa}$, and the other negative cell above.
The extratropical QBO temperature signals are out of phase with the tropical QBO ones in both hemispheres. These extratropical QBO signals arise from the secondary meridional circulation induced by the main equatorial QBO (e.g. Plumb and Bell, 1982) and can be seen preferentially in the winter hemisphere (e.g. Randel et al., 1999), where the Brewer-Dobson circulation is much stronger than in the summer hemisphere, though the extratropical QBO signal in the winter hemisphere is not analyzed all year around, i.e., it disappears some winters (Randel et al., 1999). Thus, the latitudinal symmetry in the extratropical QBO temperature signal in Fig. 13 is not the real picture but a virtual structure made through the annual mean operation.

The simulated annual-mean QBO20 ozone signal (Fig. 14) exhibits a four-cell structure over the equatorial region, a negative cell up to $60 \mathrm{hPa}$, a positive cell up to $20 \mathrm{hPa}$, the other positive cell up to $2 \mathrm{hPa}$, and the other negative 

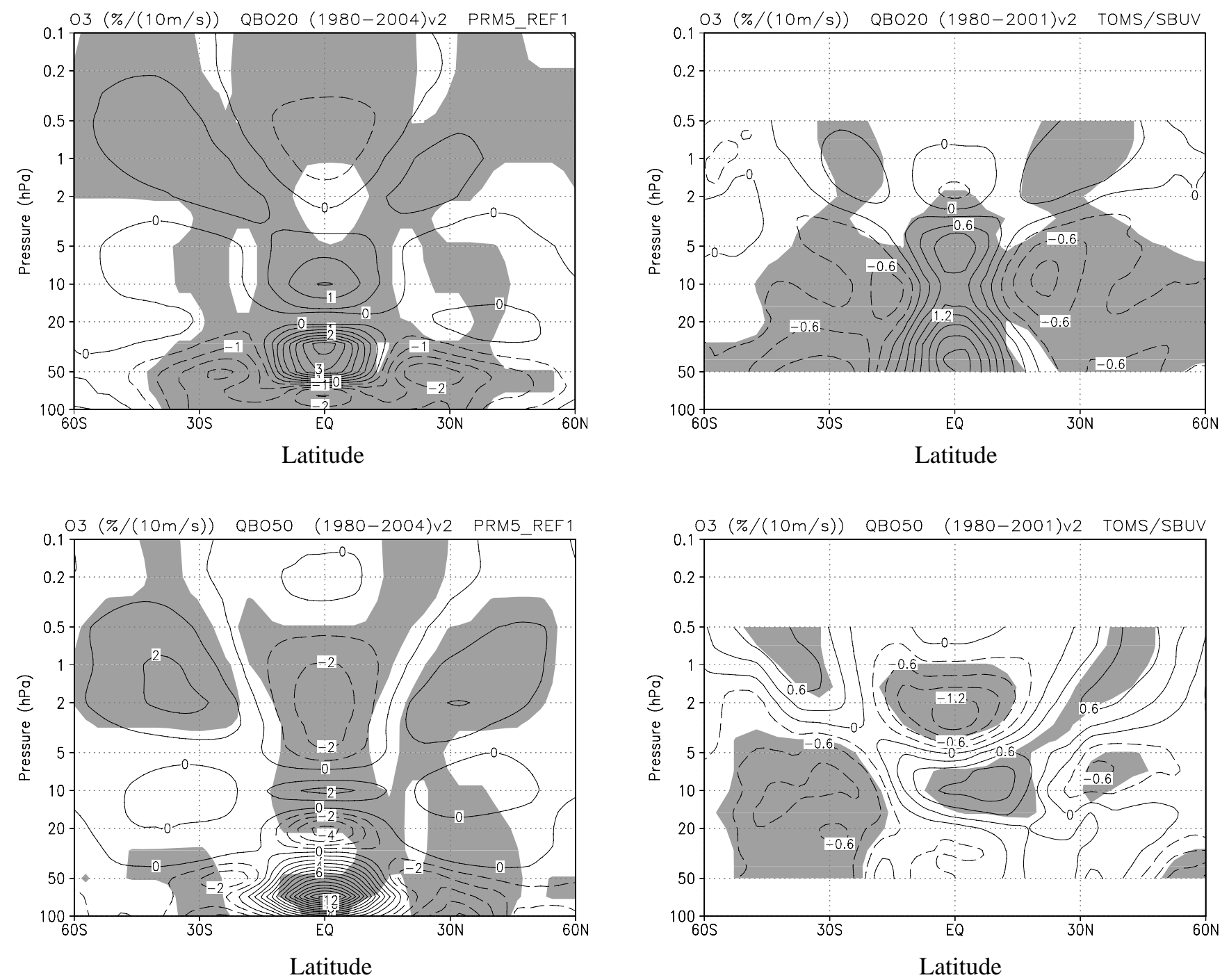

Fig. 14. Same as in Fig. 11 except for ozone in $\% /(10 \mathrm{~m} / \mathrm{s})$. Contour interval is $1 \% /(10 \mathrm{~m} / \mathrm{s})$ for the model and $0.3 \% /(10 \mathrm{~m} / \mathrm{s})$ for TOMS/SBUV.

cell above. Since a pressure level of about $20 \mathrm{hPa}$ corresponds to a critical altitude separating the photochemistry control region above and the transport control region below (e.g. Hasebe, 1994), the QBO20 ozone positive signal below $20 \mathrm{hPa}$ is consistent with the QBO20 temperature positive signal, both of which are brought by a downdraft associated with the QBO westerly shear zone. Extratropical negative signals in temperature and ozone are also consistent with each other because there is an updraft as a return arm of the equatorial QBO in each hemisphere. In contrast, the QBO20 ozone positive signal above $20 \mathrm{hPa}$ in the stratosphere can be interpreted as a response to the cooling (Ling and London, 1986) or to the transport of $\mathrm{NO}_{\mathrm{x}}$-poor air (Chipperfield et al., 1994). In the simulation, for example, the QBO20 temperature signal (Fig. 13) exhibits a major cooling peak of about $1.4 \mathrm{~K} /(10 \mathrm{~m} / \mathrm{s})$ and the $\mathrm{QBO} 20$
$\mathrm{NO}_{\mathrm{x}}$ signal (not shown) shows a very weak reduction peak of about $0.3 \times 10^{-2} \mathrm{ppbv} /(10 \mathrm{~m} / \mathrm{s})$ at $10 \mathrm{hPa}$. A detailed analysis on this, however, is beyond the scope of this paper. The simulated QBO20 ozone signal of these two positive cells below $3 \mathrm{hPa}$ qualitatively agrees with the observation (SBUV/TOMS), although the minimum value between them is too low in the simulation.

The simulated annual mean QBO50 ozone signal, which has a four-cell structure in the equatorial stratosphere (Fig. 14), qualitatively agrees with the observed one for the negative cell centered around $3 \mathrm{hPa}$, positive cell centered at $10 \mathrm{hPa}$, and negative cell centered around $30 \mathrm{hPa}$, albeit the lowest one is not statistically significant. However, the simulated positive cell below $30 \mathrm{hPa}$ with the largest magnitude centered at $70 \mathrm{hPa}$ in the equatorial lower stratosphere cannot be seen in TOMS/SBUV data in spite of there being no 
data below $50 \mathrm{hPa}$. As will be described below, this intensive positive cell in the lowermost stratosphere is the cause of a significantly large response of total ozone in the equatorial region, whereas almost no response can be seen in the observed data.

In the observed total ozone data (Fig. 15), positive values of the QBO20 signal cover the equatorial region from approximately $10^{\circ} \mathrm{S}$ to $10^{\circ} \mathrm{N}$ with a slight peak in October/November. In the extratropics, negative (out-of-phase) values extend in mid-latitudes with maxima of the same magnitude as the equatorial signal in mid-latitudes of both hemispheres during the winter-spring season in each hemisphere, March in the Northern Hemisphere, and August/September in the Southern Hemisphere. These features are very similar to those regressed to the QBO $30 \mathrm{hPa}$ wind (Randel and Cobb, 1994) or to the vertically weighted QBO wind with a peak at $20 \mathrm{hPa}$ (Randel et al., 1995).

The simulation qualitatively reproduced the observed features with similar magnitudes, but the locations or dates of maxima are skewed and the mid-latitude negative values during the winter-spring season do not extend to high latitudes in the winter hemisphere, unlike observations (e.g., Randel and Cobb, 1994) and the mechanistic chemistry model simulation (Kinnersley and Tung, 1999). In the equatorial region, a maximum appears in June/July with a weak second maximum in December, while a weak minimum appears in March. The northern mid-latitude negative maximum occurs around $40^{\circ} \mathrm{N}$ similarly to but about two months earlier than the observed one. The southern mid-latitude negative maximum appears around $30^{\circ} \mathrm{S}$ in July/August and is approximately one month earlier and 10 degrees equatorward than the observed one.

The simulated QBO50 total ozone signal has statistically significant values in the tropics, where a maximum occurs in July/August and minima appear in March and December, while the observed data has no statistically significant value in the tropics (Fig. 15). This feature in the simulation is consistent with the ozone signals in the lowermost stratosphere, where the simulated ozone has a large positive signal (Fig. 14). Statistically significant and negative (outof-phase) minima appear in the extratropics of the observed data about two month behind the QBO20 ozone minimum signals in both hemispheres. The model barely reproduced the southern mid-latitude minimum alone.

\subsection{Solar signals}

The current simulation does not include the temporal variations of photodissociation due to the solar irradiance variations as stated above, so the simulated solar signal reflects only responses to the radiative heating of the 11-year solar cycle, indicating that some attention is required to interpret the model result. Figure 16 depicts the annual mean solar temperature signals in $\mathrm{K}$ per 100 solar units from 100 to $0.1 \mathrm{hPa}$ between $60^{\circ} \mathrm{S}$ and $60^{\circ} \mathrm{N}$ for the simulation and ob- servation (ERA-40). Note that the values in Fig. 16 should be multiplied by 1.3 to obtain differences between solar maximum and minimum because the 130 solar units of F10.7 correspond, on average, to the difference between the solar maximum and minimum. The simulation has two latitudinally symmetric strong warming areas in the mesosphere and in the lower stratosphere and a cooling area in between them over the tropics. The mesospheric warming extends down to about $3 \mathrm{hPa}$ and has a broad depth peak centered at $0.5 \mathrm{hPa}$. Interestingly, the magnitude and vertical and meridional extents of this mesospheric warming are very similar to those due to the UV heating alone between solar maximum and minimum under a fixed dynamical heating assumption (Shibata and Kodera, 2005). The lower stratospheric warming extends from 20 to $80 \mathrm{hPa}$ with a peak at about $70 \mathrm{hPa}$ and this is probably due to dynamics, because UV impact scarcely penetrates into the middle stratosphere. The cooling and weak warming area between the two strong warmings is not statistically significant.

The observed annual mean solar temperature signal also has two strong warmings and a minimum warming in between with latitudinal symmetry. The observed higher altitude warming signal is shallower with a maximum around $3 \mathrm{hPa}$ and possesses a wider latitudinal extent than the simulated one. The discrepancy in the upper stratosphere between the simulation and observation is mainly from the current simulation not reproducing the ozone increase through photodissociation change in the upper stratosphere due to the 11 -year solar cycle. It is worthwhile to point out that MRICCM simulates a statistically significant 2 to $3 \%$ increase in annual mean ozone at about $3 \mathrm{hPa}$ (not shown) for the difference between solar maximum and minimum time-slice runs, in which the photodissociation process is correctly treated, as in other CCMs (e.g. Tourpali et al., 2003; Egorowa et al., 2004). On the other hand, the second maximum warming of $0.8 \mathrm{~K}$ around $50 \mathrm{hPa}$ between $30^{\circ} \mathrm{S}$ and $30^{\circ} \mathrm{N}$ in observations is reproduced in the simulation, though the height is lower and the magnitude is underestimated to be $0.5 \mathrm{~K}$. This indicates that the upper stratospheric warming associated with ozone increase due to UV enhancement might have minor effects on the tropical lower stratospheric warming.

The satellite measurements or other upper-air observations are not long enough to stably and accurately analyze the 11year solar cycle but, in total, include barely two cycles. As a result, the solar signal is detected differently depending on analysis methods or conditions employed (e.g. Scaife et al., 2000; Labitzke et al., 2002; Hood, 2004; Crooks and Gray, 2005). Even using ERA-40 data with the multiple linear regression analysis, the resultant solar temperature signal by Crooks and Gray (2005) is different, particularly in the tropical lower stratosphere, from that in this study. This is because some of the reference terms are not equivalent between the two analyses.

Figure 17 depicts the annual mean solar ozone signals in percent per 100 solar units between $60^{\circ} \mathrm{S}$ and $60^{\circ} \mathrm{N}$ for the 

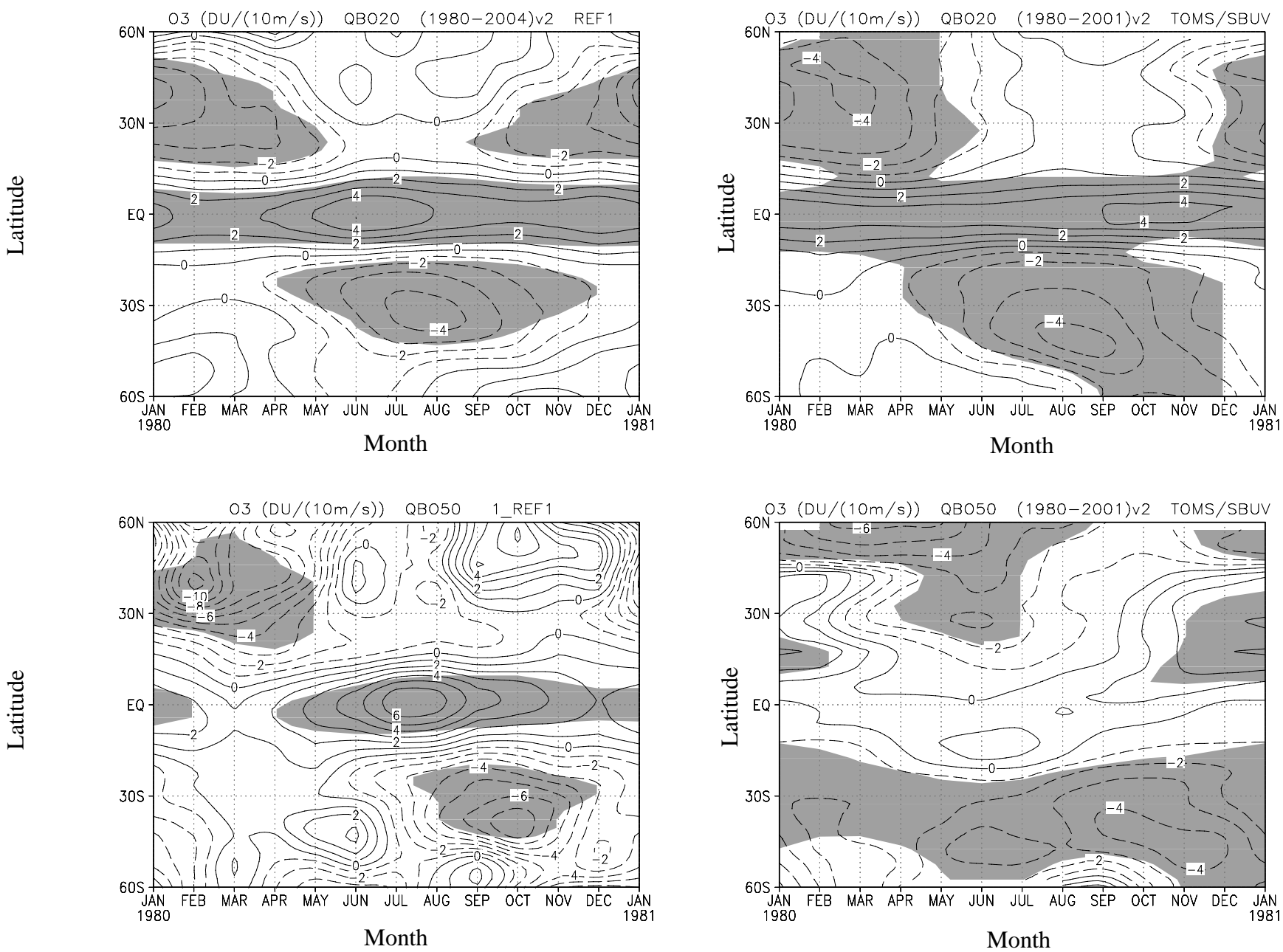

Fig. 15. Month-latitude cross sections of the QBO20 (upper) and QBO50 (lower) total ozone in DU per $10 \mathrm{~m} / \mathrm{s}$ of the QBO winds at 20 and $50 \mathrm{hPa}$ between $60^{\circ} \mathrm{S}$ and $60^{\circ} \mathrm{N}$ for the simulation (left) and observation (TOMS/SBUV) (right). Contour interval is $1 \mathrm{DU} / \mathrm{year}$, and shading denotes the $95 \%$ confidence level (t-test).

simulation and observation (TOMS/SBUV). Interestingly, without the effect of photodissociation variations, the simulation reproduced a positive maximum signal around $3 \mathrm{hPa}$ and a negative signal around $20 \mathrm{hPa}$ in the tropics, and the positive signal has a wider latitudinal extent with better symmetry than the negative signal. This dipole vertical structure is also seen in the observed signal, although the two observed signals are located at higher altitudes. Note that the negative signal can also be analyzed in TOMS/SBUV and SAGE data (Lee and Smith, 2003; Hood, 2004; Randel and Wu, 2007), but the statistical significance is low in both satellite data (Hood, 2004; Randel and Wu, 2007). In the tropical lower stratosphere, however, the simulated positive signal seems to be related to mid-latitude positive signals of both hemispheres and is very different from the observed signal.

\subsection{Volcanic signals}

Figure 18 displays the evolutions of the simulated global $\left(65^{\circ} \mathrm{S}\right.$ to $\left.65^{\circ} \mathrm{N}\right)$ volcanic temperature signals for about a half year before and about three and a half years after the El Chichón and Mount Pinatubo eruptions, along with the observed signals (ERA-40). The model reproduced qualitatively well the warming due to El Chichón volcanic aerosols with respect to its timing and extent until the middle of 1983 , but after this date the model failed to simulate the observed seasonal cycle, which peaks during the northern autumn in 1983 and 1984. After the Mount Pinatubo eruption, the model reproduced the observed warmings such as the first warming in the 1991/92 winter, the second and third warmings during autumn in 1992 and 1993, albeit an excess weak warming during the early summer in 1992. Quantitatively, however, the model overestimates the warming magnitude for the two eruptions, in particular for El Chichón, as in 

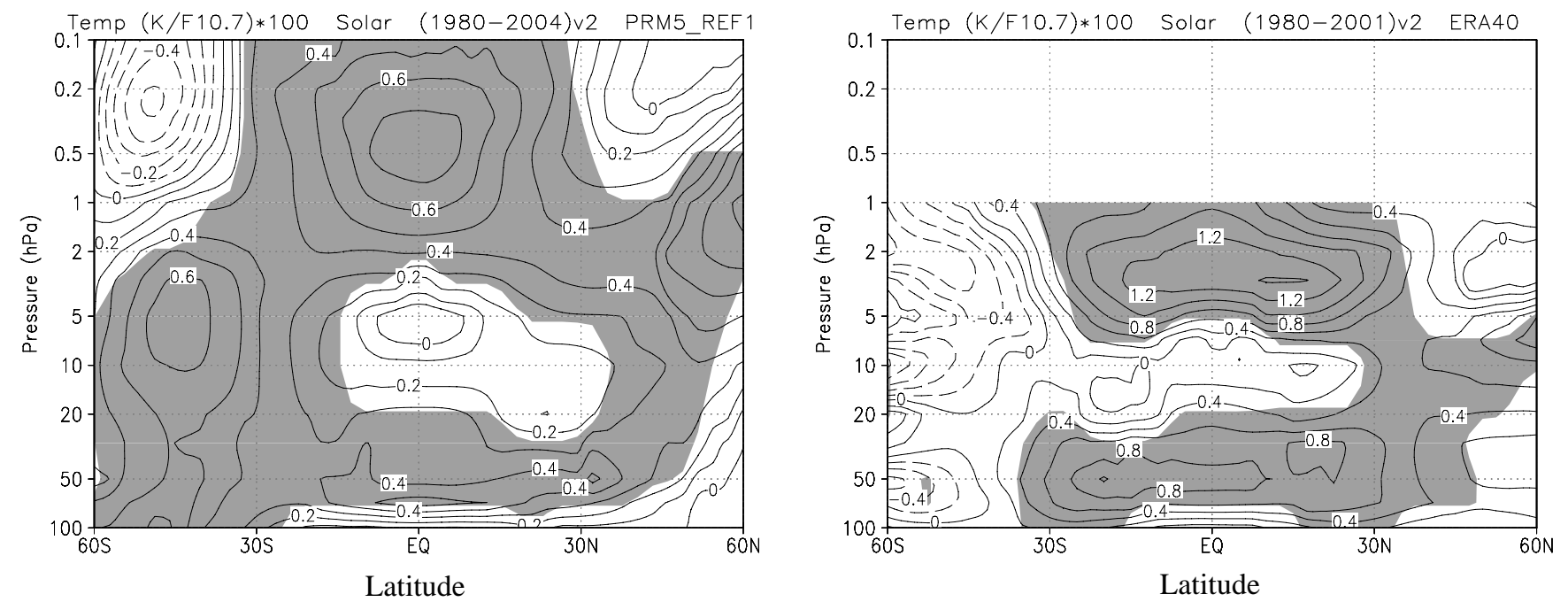

Fig. 16. Latitude-pressure cross sections of the solar temperature signals in $\mathrm{K}$ per 100 solar units from 100 to $0.1 \mathrm{hPa}$ between $60^{\circ} \mathrm{S}$ and $60^{\circ} \mathrm{N}$ for the simulation (left) and observation (ERA-40) (right). Contour interval is 0.1 for the simulation and 0.2 for the observation, and shading denotes the $95 \%$ confidence level (t-test).

O3 (\%/F10.7)*100 Solar (1980-2004)v2 PRM5_REF1

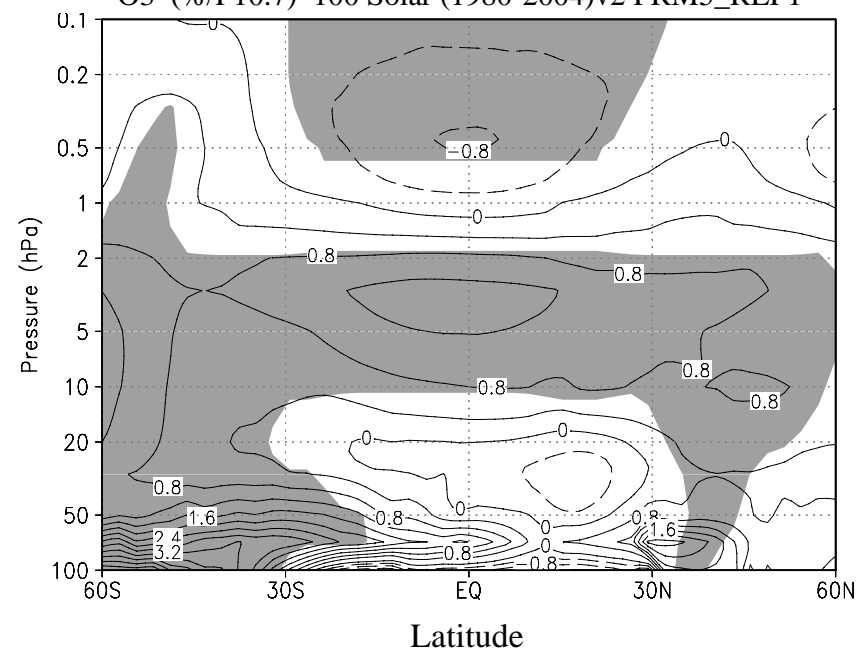

O3 (\%/F10.7)*100 Solar (1980-2004)v2 TOMS/SBUV

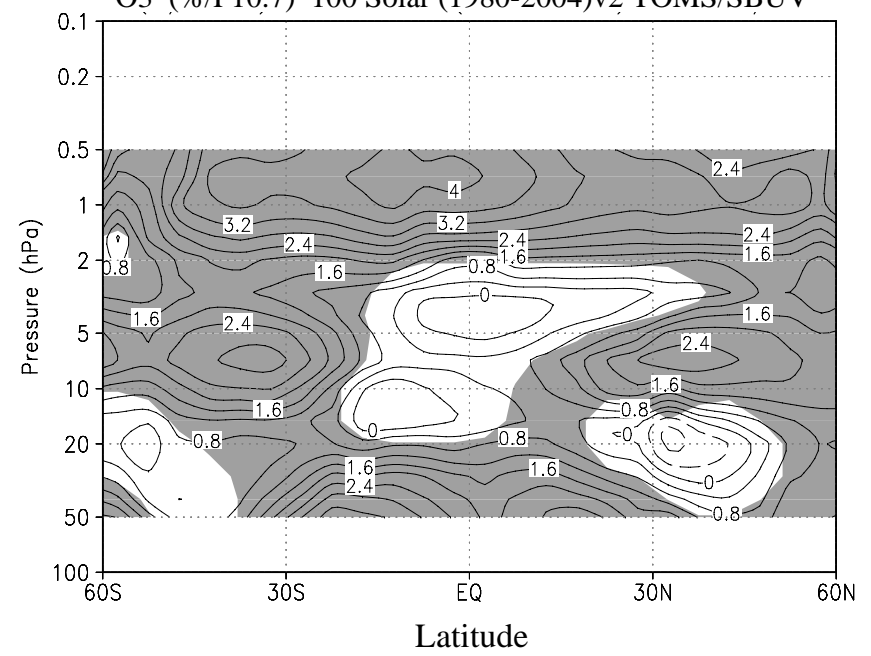

Fig. 17. Same as in Fig. 16 except for ozone in $\%$ per 100 solar units for the simulation (left) and observation (TOMS/SBUV) (right). Contour interval is 0.4 .

other model simulations (e.g. Dameris et al., 2005; Kirchner et al., 1999). One reason for this is the disagreement between the simulated and observed QBOs, because the QBO significantly impacts the effect of volcanic aerosols (e.g. Randel et al., 1995) through the mean meridional circulation.

When El Chichón erupted, the ERA-40 QBO wind was easterly and had almost peaked at $50 \mathrm{hPa}$, above which strong westerly shear was descending (Fig. 2), while the simulated QBO wind is approximately westerly and reaches maximum at $50 \mathrm{hPa}$, indicating that the QBO phase in ERA-40 is opposite to that in the simulation. However, during the eruption of Mount Pinatubo, the observed QBO wind at $50 \mathrm{hPa}$ is almost a transition state from westerly to easterly and the westerly lasts abnormally long, i.e. the descent of the next easterly stalls for several months around $50 \mathrm{hPa}$ (Fig. 2), after the eruption. The simulated QBO wind is near a peak value, and no abnormal feature can be seen for the descent of the next westerly after the eruption. Such differences in the QBO phase against the eruptions between the observed and simulated data are in part responsible for the CCM errors because the vertical shear of the QBO is directly related to the secondary meridional circulation, which produces large effects in up- and downdraft regions. In addition, these differences might produce the difference in the response errors 

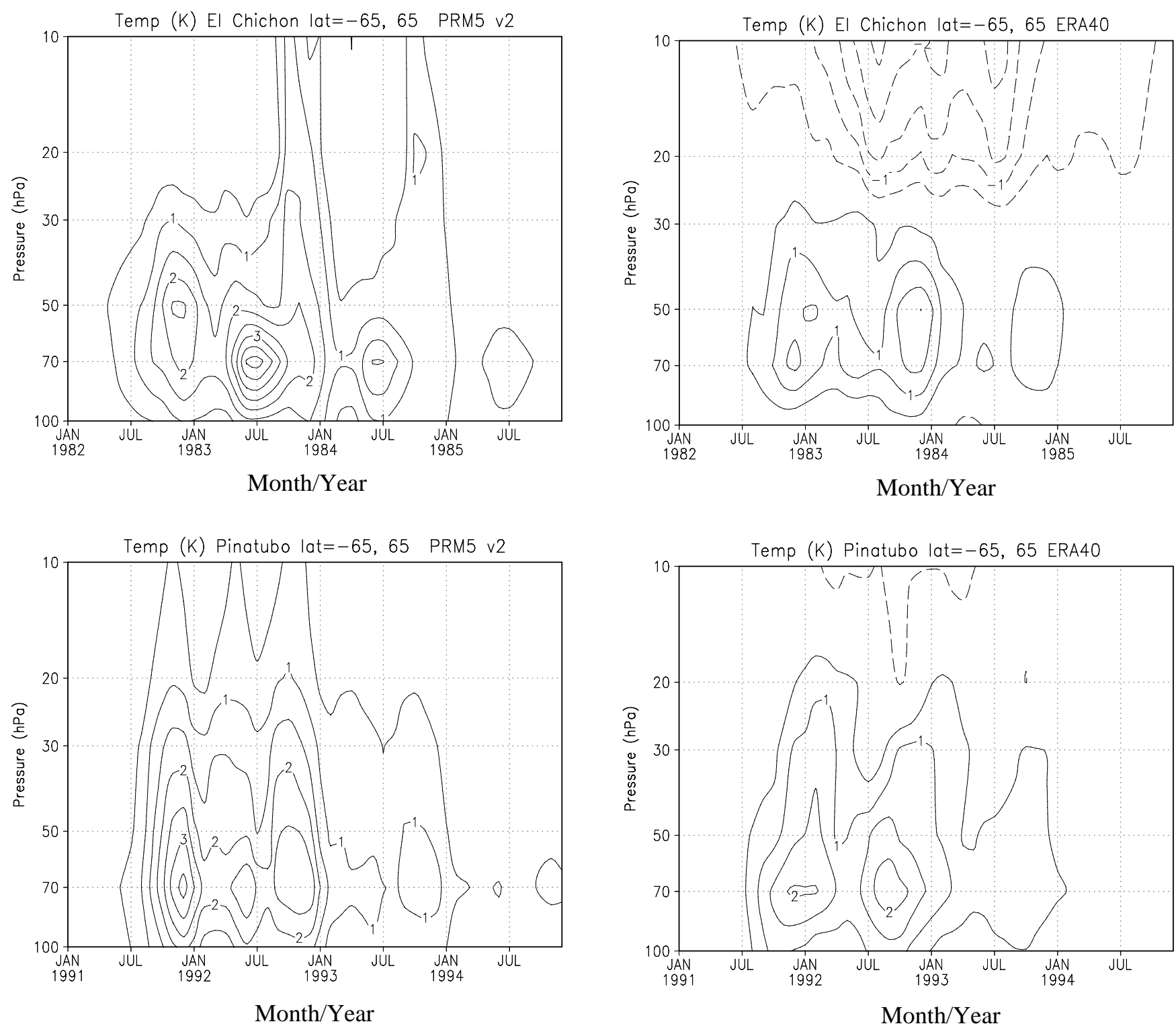

Fig. 18. Time-pressure cross sections of the global $\left(65^{\circ} \mathrm{S}\right.$ to $\left.65^{\circ} \mathrm{N}\right)$ temperature after the El Chichón eruption (upper) and Mount Pinatubo eruption (lower) for the simulation (left) and observation (ERA-40) (right). Contour interval is $0.5 \mathrm{~K}$ and dashed contours denote negative values. Zero contours are omitted.

of the CCM between the two eruptions, although the spatial distribution of the volcanic aerosols is based on observations and has nothing to do with the QBO phase in the CCM.

The global $\left(65^{\circ} \mathrm{S}\right.$ to $\left.65^{\circ} \mathrm{N}\right)$ volcanic total ozone signals for the El Chichón and Mount Pinatubo eruptions are depicted in Fig. 19. The simulated ozone decrease peaked in February 1983 similar to the observed one for the El Chichón eruption, but the simulated magnitude was about two-fold larger than the observed one. Other ozone decrease extremes in August 1982 and 1983, January 1984, and February 1985 were underestimated but their timings were correctly reproduced, although the simulated extreme in July 1984 cannot be seen in the observation. For the Mount Pinatubo eruption, the simulation does not capture the observed features well, except for the temperature signal. The simulated ozone decrease peaked in March 1992, about four months after the observed maximum decrease in October 1992, and its magnitude is about three-fold larger than the observed one. In addition, other observed ozone peaks centered in August 1992 and 1993 are not reproduced at all in the simulation. The overall overestimation in the simulated ozone decrease comes primarily from an overestimation of ozone loss due to the heterogeneous reactions on the volcanic aerosol surface, because the gas-phase reactions could not produce such a severe ozone decrease. 

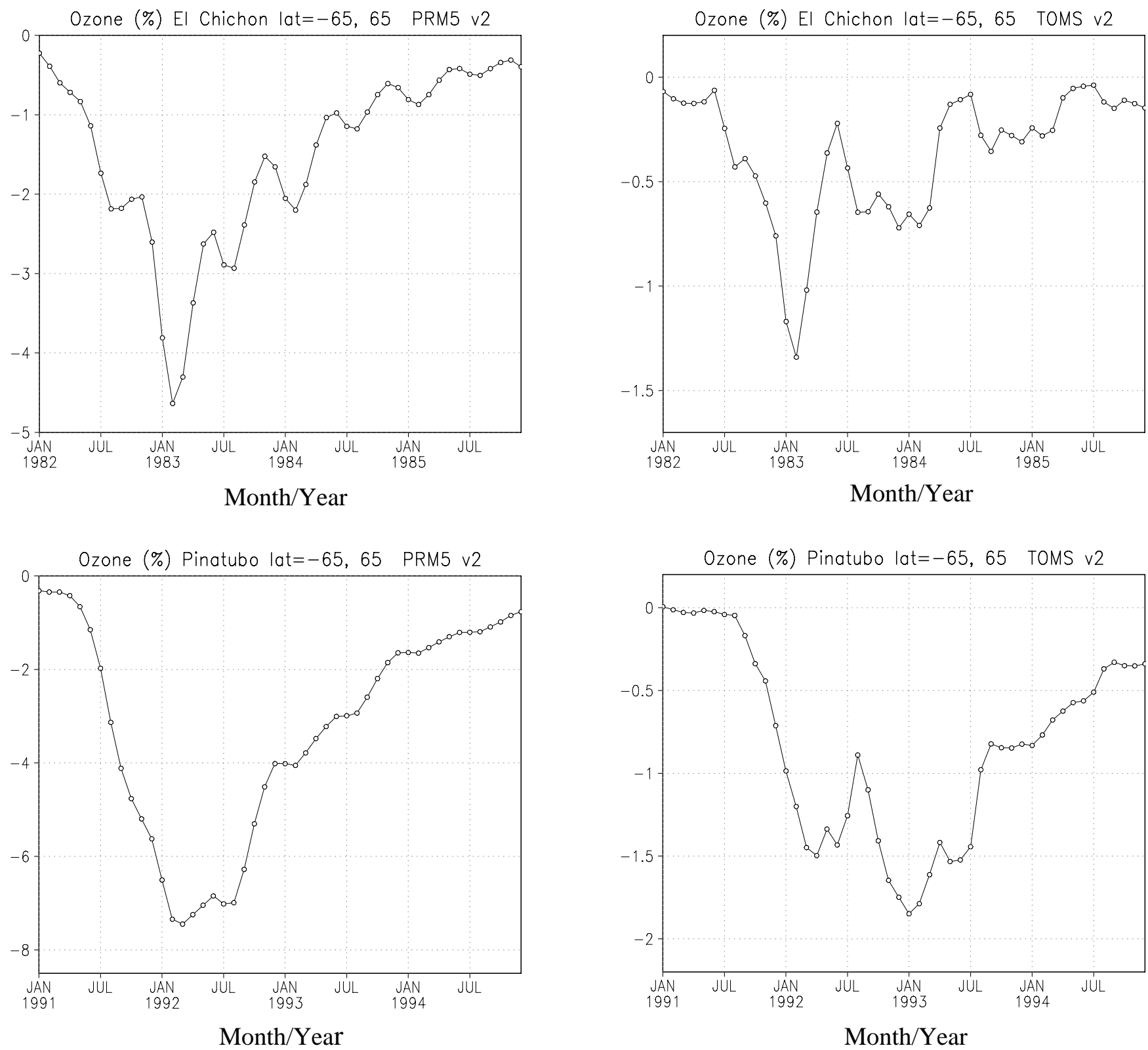

Fig. 19. Evolution of the global total ozone after the El Chichón eruption from 1982 to 1985 (upper) and Mount Pinatubo eruption from 1991 to 1994 (lower) for the simulation (left) and observation (TOMS/SBUV) (right).

Furthermore, radiative and dynamic effects are also responsible for this overestimation (e.g. Tie et al, 1994; Kinnison et al., 1994). The radiative effect refers to the warming below the middle stratosphere due to the solar and terrestrial heating of volcanic aerosols, leading to increases in the reaction rates of odd-oxygen loss, and the dynamic effect refers to the enhanced upward transport of ozone-poor air, which is a dynamic response to the radiative heating. Both effects thereby induce ozone loss below the middle stratosphere in the tropics.

\subsection{ENSO signals}

Figure 20 depicts the annual average ENSO signals of zonalmean temperature (K per -1 standard deviation of SOI) from 1000 to $1 \mathrm{hPa}$ for the simulation and observations. ENSO is a coupled ocean-atmosphere fluctuation with east-west seesawing SST between the eastern and the western tropical Pacific Ocean. The SST in the eastern tropical Pacific rises by 1 to $2 \mathrm{~K}$ above normal during an El Niño warm event and decreases by a similar amount below normal during a $\mathrm{La}$ Niña cold event (e.g. Philander, 1989). In addition, ENSO 

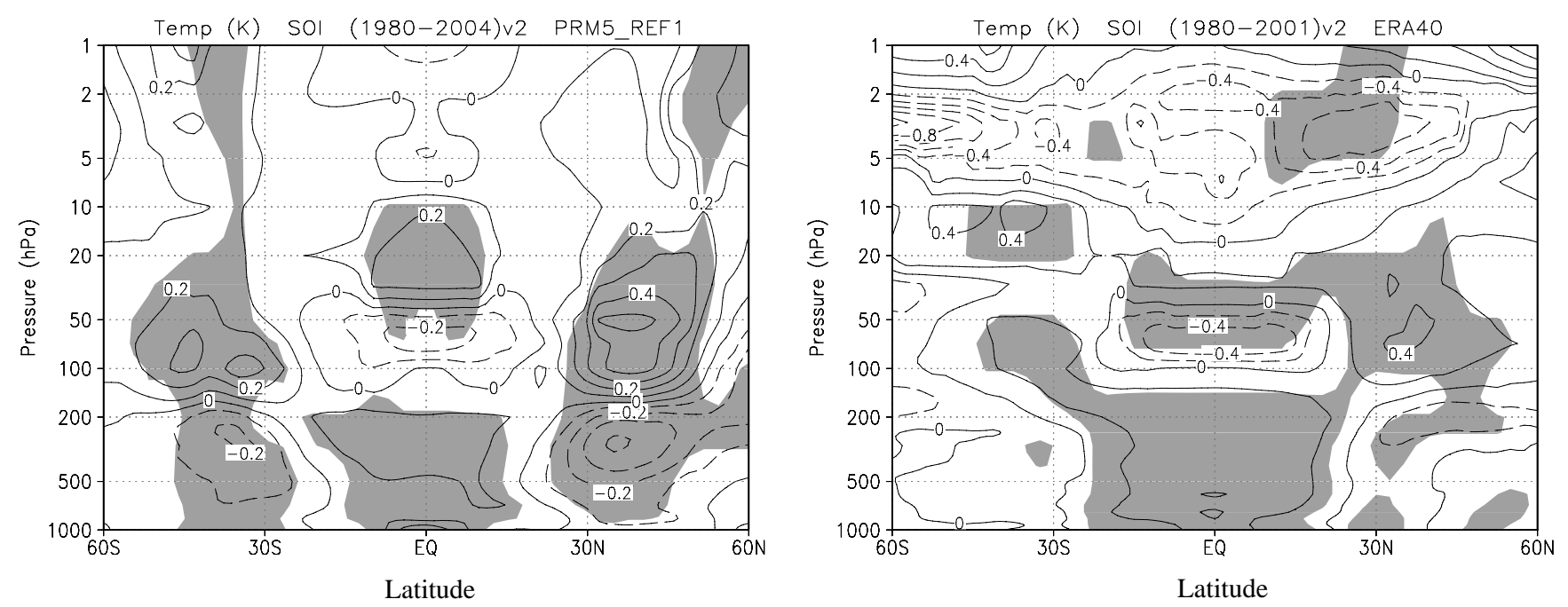

Fig. 20. Latitude-pressure cross sections of the annual average ENSO signal of zonal-mean temperature in $\mathrm{K}$ per -1 standard deviation of SOI between $60^{\circ} \mathrm{S}$ and $60^{\circ} \mathrm{N}$ for the simulation (left) and observation (ERA-40) (right). Contour interval is 0.1 for the simulation, and 0.2 for ERA-40. Shading denotes the $95 \%$ confidence level (t-test).

possesses strong seasonality such that the atmospheric response becomes largest during the northern winter, though it can be seen in other seasons. The zonal-mean component with annual averaging as shown in Fig. 20 is thus smaller than the non-zonal component during the mature stage. The tropical troposphere warming during El Niño in Fig. 20 is due to the latent heat release increase coming from enhanced convective activity. The cooling below the middle stratosphere in the tropics (Reid, 1994; Crooks and Gray, 2005) is due to an enhanced updraft (not shown), while the midlatitude, warming in the 20 to $150 \mathrm{hPa}$ region centered around $35^{\circ} \mathrm{S}$ and $35^{\circ} \mathrm{N}$, is caused by an enhanced downdraft (not shown). The CCM reproduced well the spatial pattern of the tropospheric warming and the stratospheric cooling in the tropics, while the amplitudes are about a half of the observed ones. The mid-latitude stratospheric warmings in the simulation are slightly larger than the observed warmings.

The annual average ENSO signal of zonal-mean zonal wind (Fig. 21) demonstrates that the tropospheric response occurs virtually in the subtropics, peaking at about $25^{\circ} \mathrm{S}$ and $25^{\circ} \mathrm{N}$ (Crooks and Gray, 2005). The intensification of the subtropical jet thus occurs in the equatorward flank in both hemispheres and is approximately in thermal wind balance with the ENSO temperature signal. The CCM reproduced the subtropical jet response with regard to the strength and extent, though the response is somewhat underestimated in both quantities. However, there are large discrepancies between the simulated and the observed signals in the tropical stratosphere. One reason could be interference between QBO and ENSO through aliasing in the multiple linear regression model (Crooks and Gray, 2005).

Figure 22 illustrates the annual average ENSO signal of zonal-mean ozone from 100 to $0.1 \mathrm{hPa}$ for the simulation and observations (TOMS/SBUV). Due to the enhanced updraft in the tropics and the corresponding downdraft in the midlatitudes of both hemispheres, there is an ozone decrease in the tropics and an ozone increase in the mid-latitudes centered at $35^{\circ} \mathrm{S}$ and $35^{\circ} \mathrm{N}$ for both the simulation and observation. It should be noted that the ozone decrease in the tropics occupies a thicker region below $15 \mathrm{hPa}$ than the cooling below $50 \mathrm{hPa}$ and that it is latitudinally asymmetric in contrast to the symmetric cooling.

\section{Discussion}

The QBO in the equatorial stratosphere crucially affects the stratospheric dynamics in both the tropics and in mid- and high latitudes through the wave-mean flow interaction. For the westward QBO wind, a zero-wind line seems to work as a critical line (e.g. Andrews et al., 1987) for stationary planetary waves in the winter hemisphere, and stationary planetary waves are thereby apt to deflect poleward, leading to their larger westward momentum deposition in high latitudes. As a result, a weaker polar vortex and warmer polar temperature appear. For the eastward QBO wind, however, there is no critical line in the winter hemisphere, so that stationary planetary waves are apt to deflect equatorward, inducing a stronger polar vortex and colder polar temperature. This relation between the QBO phase and the polar vortex magnitude in the Northern Hemisphere was first demonstrated by Holton and Tan (1980) from monthly data for a 16-year period (1962 to 1977), but the statistical significance was marginal due to the small numbers of the QBO phase. Recently, Naito and Yoden (2005) proved that the above relation (Holton-Tan relation) holds true with high 

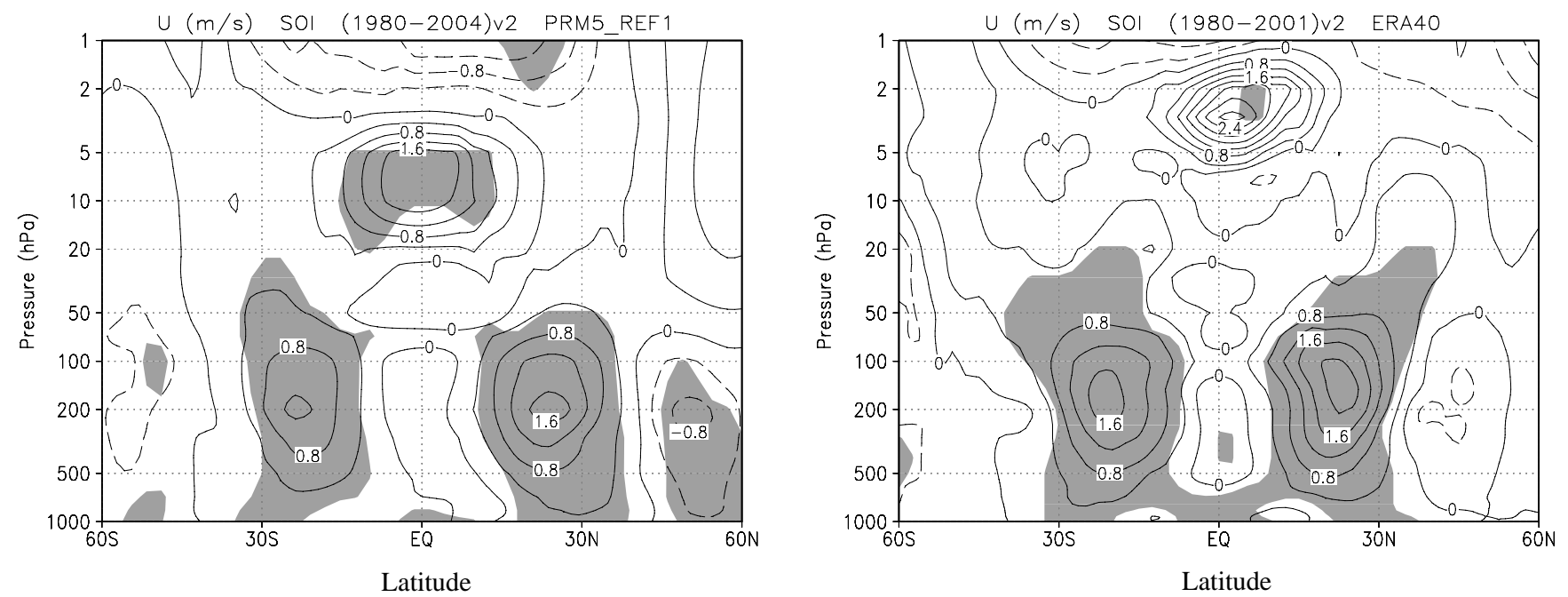

Fig. 21. Same as in Fig. 20 except for zonal wind in $\mathrm{m} / \mathrm{s}$, and contour interval is 0.4 .
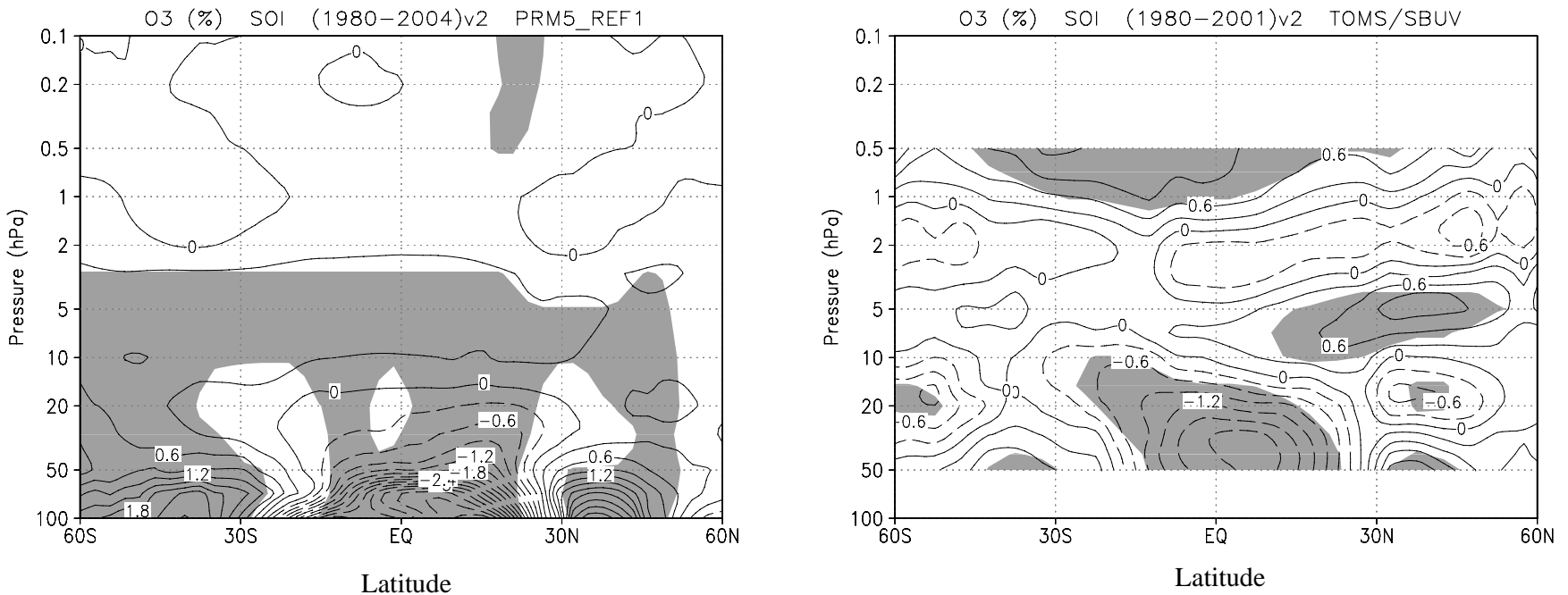

Fig. 22. Same as in Fig. 20 except for ozone in $\%$ with the observation being TOMS/SBUV, and contour interval is 0.1 .

statistical significance (>99\%) from long-term daily data of NCEP/NCAR Reanalysis (Kalnay et al., 1996) for 46 years (1958 to 2003) based on the large-sample method. Pascoe et al. (2005) also obtained statistically significant results for the Holton-Tan relation from ERA-40 for 1979 to 2001. The Holton-Tan relation can also be reproduced with threedimensional mechanistic models (e.g. Holton and Austin, 1991; Hampson and Haynes, 2006) and with GCMs by imposing the observed QBO wind (Hamilton, 1998).

The simulated QBO has a smaller amplitude and a shorter period than the observed QBO (Figs. 2 and 8), and thus the mean meridional circulation associated with the QBO also differs with respect to period and intensity, giving rise to different influences on chemical constituents in the tropics. In addition, both the zonal wind field in the subtropical strato- sphere and the phase relationship between the QBO and seasonal cycle in the simulation substantially differ from those in observations, causing different extratropical responses to the QBO. This is because the phase alignment or relationship between the QBO and seasonal cycle plays an important role in the extratropical responses (e.g. Gray and Dunkerton, 1990; Hampson and Haynes, 2006).

The QBO also affects the responses to the 11-year solar cycle (e.g. Labitzke, 1987; Labitzke and van Loon, 1988) and volcanic aerosols (e.g. Randel et al., 1995; Lee and Smith, 2003), so that the simulated responses to these forcings may be skewed to a certain degree due to the differently reproduced QBO, requiring some caution in interpreting the model result. The response to volcanic aerosols due to eruptions in the tropics such as the El Chichón and Mount Pinatubo 
eruptions especially needs a correct phase relationship with the QBO because the large amount of volcanic aerosols initially formed in the QBO domain are subject to dynamical heating or cooling associated with the mean meridional circulation depending on the QBO phase. For example, if the simulated QBO phase is westerly, i.e. opposite to the observed easterly phase, then radiative heating due to volcanic aerosols and dynamical heating are both positive, leading to warming errors. For the correct QBO phase (easterly), dynamics brings cooling through the downdraft, resulting in the suppression of radiative heating.

The simulated trend is probably free from the effect of the QBO because the simulated QBO wind does not exhibit a trend like the observed one. However, the validity of the assumption used in the multiple linear regression analysis on ozone must be treated with care. Specifically, the trend of annual mean ozone is linear everywhere over the entire period from 1980 to 2004. The observed ozone, however, has recently exhibited a turnaround over certain latitude and altitude ranges. Fioletov et al. (2002), for example, found that ground-based station and satellite (TOMS and TOMS/SBUV) total ozone had no practical decreasing trend from 1988 to 2000 in northern mid-latitudes $\left(35^{\circ}\right.$ to $\left.60^{\circ} \mathrm{N}\right)$. Newchurch et al. (2003) demonstrated that SAGE I/II combined with HALOE data provides evidence of a slowdown in stratospheric ozone losses since 1997. Hadjinicolaou et al. (2005) showed that TOMS/SBUV total ozone increased between $35^{\circ}$ and $60^{\circ} \mathrm{N}$ after 1994 , in contrast to a decreasing trend over the previous years (1979 to 1993) and that this upward trend is reproduced by the CTM forced only by transport changes. Therefore, a piecewise-linear model, rather than a linear model (e.g. Reinsel et al., 2005), is preferable for accurate representation of the observed trend and simulated trend more accurately, in spite of the increase of parameters.

\section{Summary}

A simulation of the middle atmosphere for the past 25 years (from 1980 to 2004) was performed with MRI-CCM by imposing observed natural and anthropogenic forcings of SST, sea ice, greenhouse gases, halogens, the 11-year solar cycle, and volcanic aerosols. These forcings are introduced daily through interpolation from monthly mean values. The monthly mean SSTs are corrected to retain temporal variability even when interpolated from monthly to daily values. The concentrations of well-mixed GHGs $\left(\mathrm{CO}_{2}, \mathrm{CH}_{4}\right.$, and $\left.\mathrm{N}_{2} \mathrm{O}\right)$ and those of halogens are specified at the surface. In addition, the abundance of each chlorine-bearing species is multiplied by a constant factor $(\sim 1.3)$ each month to realistically represent the abundance of total chlorine atoms $\left(\mathrm{CCl}_{\mathrm{y}}\right)$ in organic chlorine compounds. After the simulation, the solar forcing was found to have an error that prevented the photodissociation coefficients from being varied with the solar cycle, so that the 11-year solar cycle exerted forcing on the model through radiation alone.

MRI-CCM adopts a hybrid semi-Lagrangian transport scheme, which is an ordinary semi-Lagrangian scheme in the horizontal direction and equivalent to a mass-conserving flux form in the vertical direction. The current PRM5 scheme, which uses a quintic interpolation in the horizontal direction and employs a piecewise rational method for overhead column abundances in the vertical direction, produced a substantial decrease of ozone positive biases, particularly in the tropical upper troposphere and lower stratosphere, compared to the previous scheme with cubic interpolation for both the horizontal and vertical directions. As a side-effect of the decrease of ozone in the tropical lower stratosphere, the QBO period shortened from 31 to 20 months through the decrease of the solar-heating feedback of ozone. The other features of the QBO are very similar to those of the previous one with a 31-month period simulated under annually repeating forcings.

Multiple linear regression analysis has been performed for temperature, zonal wind, and ozone to separate the trend, the QBO, the El Chichón and Mount Pinatubo, the 11year solar cycle, and the ENSO signals for the simulation and observations. It was found that MRI-CCM can more or less realistically reproduce the observed trend of annual mean temperature and ozone such as a maximum cooling of $2.5 \mathrm{~K} /$ decade near the tropical and subtropical stratopause and a maximum ozone decrease of 12 to $14 \%$ /decade at 2 to $3 \mathrm{hPa}$ height around 30 to $60^{\circ}$ latitude in both hemispheres. The total ozone exhibits severe spring-time decreases of 3 to $4 \% /$ decade in the northern high latitudes and of 5 to $6 \% /$ decade in the southern high latitudes, which is $1 \% /$ decade higher and $2 \% /$ decade higher than the observed values.

The annual mean QBO signals of temperature and zonal wind are well reproduced as for the meridional structures, which have two- or three-cell forms of alternating sign in the stratosphere in spite of a shorter QBO period of 20 months. Similarly, the simulated ozone QBO signal also captures the observed meridional structure of vertical multi-cells. The seasonality of the mid-latitude total ozone QBO, which extends poleward with the opposite sign of the equatorial total ozone QBO in the winter hemisphere, is also quantitatively reproduced for the QBO20 signal, albeit there is no extension to high latitudes in the spring time.

The vertical three-cell structure of alternating sign in the tropical stratospheric temperature and ozone due to the 11year solar cycle is qualitatively simulated, though the photodissociation coefficients are held constant irrespective of the solar cycle. The simulated solar signal in the upper stratosphere and above, where photodissociation plays a crucial role, does not reflect the photochemical response to UV evolution but rather reflects the radiative response, so that careful attention is required for interpreting the solar signal of this study. Nevertheless, the fact that the second maxima 
of temperature and ozone in the tropical lower stratosphere and the minima above are reproduced demonstrates that the dynamic effect is much larger than the photochemical effect below the middle stratosphere in the tropics.

The global $\left(65^{\circ} \mathrm{S}\right.$ to $\left.65^{\circ} \mathrm{N}\right)$ volcanic temperature increase signals due to the El Chichón and Mount Pinatubo eruptions are twice as large as the observed signals, but the seasonal variations are approximately the same because the spatial distribution and radiative properties of the volcanic aerosols are based on the observed values. However, the global volcanic ozone decrease signals are significantly overestimated, in particular for Mount Pinatubo, though the observed surface-area densities of the volcanic aerosols are imposed.

The annual average ENSO signal for the zonal mean temperature in the tropics is well reproduced in terms of the spatial pattern of the tropospheric warming and the stratospheric cooling, although the amplitudes are underestimated by about half. The simulated mid-latitude stratospheric warmings in both hemispheres are slightly higher than the observed values. The ENSO signal of zonal-mean zonal wind, represented as the subtropical jet intensification in the equatorward flank in both hemispheres, is also well captured. The stratospheric ENSO ozone signal, revealed as an ozone decrease in the tropics and an ozone increase in the midlatitudes centered at about $35^{\circ} \mathrm{S}$ and $35^{\circ} \mathrm{N}$, though slightly overestimated, is well reproduced.

Acknowledgements. This study was supported by Grants-in-Aid (16340144 and 19340135) for Scientific Research from the Ministry of Education, Culture, Sports, Science and Technology of Japan and also by the Global Environmental Research Fund (GERF) of the Ministry of the Environment (MOE) of Japan (A-1).

Topical Editor U.-P. Hoppe thanks two anonymous referees for their help in evaluating this paper.

\section{References}

Andrews, D. G., Holton, J. R., and Leovy, C. B.: Middle Atmosphere Dynamics, International Geophysics Series, 40, Academic Press, Orlando, USA, 1987.

Austin, J. and Wilson, R. J.: Ensemble simulations of the decline and recovery of stratospheric ozone, J. Geophys. Res., 111, doi:10.1029/2005JD006907, 2006.

Austin, J., Shindell, D., Beagley, S. R., Brühl, C., Dameris, M., Manzini, E., Nagashima, T., Newman, P., Pawson, S., Pitari, G., Rozanov, E., Schnadt, C., and Shepherd, T. G.: Uncertainties and assessments of chemistry-climate models of the stratosphere, Atmos. Chem. Phys., 3, 1-27, 2003, http://www.atmos-chem-phys.net/3/1/2003/.

Baldwin, M. P. and Gray, L. J.: Tropical stratospheric zonal winds in ECMWF ERA-40 reanalysis, rocketsonde data, and rawinsonde data, Geophys. Res. Lett., 32, L09806, doi:10.1029/2004GL022328, 2005.

Baldwin, M. P., Gray, L. J., Dunkerton, T. J., Hamilton, K., Haynes, P. H., Randel, W. J., Holton, J. R., Alexander, M. J., Hirota, I., Horinouchi, T., Jones, D. B. A., Kinnersley, J. S., Marquardt, C.,
Sato, K., and Takahashi, M.: The quasi-biennial oscillation, Rev. Geophys., 39, 179-229, 2001.

Bodeker, G. E., Scott, J. C., Kreher, K., and McKenzie, R. L.: Global ozone trends in potential vorticity coordinates using TOMS and GOME intercompared against the Dobson network: 1978-1998, J. Geophys. Res., 106, 23 029-23 042, 2001.

Bojkov, R., Bishop, L., Hill, W. J., Reinsel, G. C., and Tiao, G. C.: A statistical trend analysis of revised Dobson total ozone data over the Northern Hemisphere, J. Geophys. Res., 95, 9785-9807, 1990.

Brasseur, G.: The response of the middle atmosphere to long-term and short-term solar variability: A two dimensional model, J. Geophys. Res., 98, 23 079-23 090, 1993.

Burrage, M. D., Vincent, R. A., Mayr, H. G., Skinner, W. R., Arnold, N. F., and Hays, P. B.: Long-term variability in the equatorial middle atmosphere zonal wind, J. Geophys. Res., 101, 12 847-12 854, 1996.

Butchart, N., Scaife, A. A., Austin, J., Hare, S. H. E., and Knight, J. R.: Quasi-biennial oscillation in ozone in a coupled chemistry-climate model, J. Geophys. Res., 108, 4486, doi:10.1029/2002JD003004, 2003.

Butchart, N., Scaife, A. A., Bourqui, M., de Grandpre, J., Hare, S. H. E., Kettleborough, J., Langematz, U., Manzini, E., Sassi, F., Shibata, K., Shindell, D., and Sigmond, M.: Simulation of anthropogenic change in the strength of the BrewerDobson circulation, Clim. Dynam., 27, D16314, 727-741, doi:10.1007/s00382-006-0162-4, 2006.

Chipperfield, M. P.: Multiannual simulations with a threedimensional chemical transport model, J. Geophys. Res., 104, 1781-1805, 1999.

Chipperfield, M. P., Gray, L. J., Kinnersley, J. S., and Zawodny, J.: A two-dimensional model study of the QBO signal in SAGE II $\mathrm{NO}_{2}$ and $\mathrm{O}_{3}$, Geophys. Res. Lett., 21, 589-592, 1994.

Chubachi, S.: Preliminary result of ozone observations at Syowa Station from February 1982 to January 1983, Mem. Natl. Inst. Polar Res. Japan., Spec. Issue, 34, 13-20, 1984.

Colella, P. and Woodward, P. R.: The piecewise parabolic method (PPM) for gas-dynamical simulations, J. Comput. Phys., 54, 174-201, 1984.

Coughlin, K. and Tung, K. K.: Eleven-year solar cycle signal throughout the lower atmosphere, J. Geophys. Res., 109, D21105, doi:10.1029/2004JD004873, 2004.

Crooks, S. A. and Gray, L. J.: Characterization of the 11-year solar signal using a multiple regression analysis of the ERA-40 dataset, J. Clim., 18, 996-1015, 2005.

Dameris, M., Grewe, V., Ponater, M., Deckert, R., Eyring, V., Mager, F., Matthes, S., Schnadt, C., Stenke, A., Steil, B., Brühl, C., and Giorgetta, M. A.: Long-term changes and variability in a transient simulation with a chemistry-climate model employing realistic forcings, Atmos. Chem. Phys., 5, 2121-2145, 2005, http://www.atmos-chem-phys.net/5/2121/2005/.

Deshler, T., Anderson-Sprecher, R., Jäger, H., Barnes, J., Hofmann, D. J., Clemesha, B., Simonich, D., Osborn, M., Grainger, R. G., and Godin-Beekmann, S.: Trends in the nonvolcanic component of stratospheric aerosol over the period 1971-2004, J. Geophys. Res., 111, D1201, doi:10.1029/2005JD006089, 2006.

Egorova, T., Rozanov, E., Manzini, E., Haberreiter, M., Schmutz, W., Zubov, V., and Peter, T.: Chemical and dynamical response to the 11-year variability of the solar irradiance simulated with 
a chemistry-climate model, Geophys. Res. Lett., 31, L06119, doi:10.1029/2003GL019294, 2004.

Eyring, V., Harris, N. R. P., Rex, M., Shepherd, T. G., Fahey, D. W., Amanatidis, G. T., Austin, J., Chipperfield, M. P., Dameris, M., Forster, P. M. De F., Gettelman, A., Graf, H. F., Nagashima, T., Newman, P. A., Pawson, S., Prather, M. J., Pyle, J. A., Salawitch, R. J., Santer, B. D., and Waugh, D. W.: A strategy for processoriented validation of coupled chemistry-climate models, B. Am. Meteorol. Soc., 86, 1117-1133, 2005.

Eyring, V., Butchart, N., Waugh, D. W., Akiyoshi, H., Austin, J., Bekki, S., Bodeker, G. E., Boville, B. A., Brühl, C., Chipperfield, M. P., Cordero, E., Dameris, M., Deushi, M., Fioletov, V. E., Frith, S. M., Garcia, R. R., Gettelman, A., Giorgetta, M. A., Grewe, V., Jourdain, L., Kinnison, D. E., Mancini, E., Manzini, E., Marchand, M., Marsh, D. R., Nagashima, T., Newman, P. A., Nielsen, J. E., Pawson, S., Pitari, G., Plummer, D. A., Rozanov, E., Schraner, M., Shepherd, T. G., Shibata, K., Stolarski, R. S., Struthers, H., Tian, W., and Yoshiki, M.: Assessment of temperature, trace species, and ozone in chemistry-climate model simulations of the recent past, J. Geophys. Res., 111, D22308, doi:10.1029/2006JD007327, 2006.

Farman, J. C., Gardiner, B. G., and Shanklin, J. D., Large losses of total ozone in Antarctica reveal seasonal ClOx/NOx interaction, Nature, 315, 207-210, doi:10.1038/315207a0, 1985.

Fioletov, V. E., Bodeker, G. E., Miller, A. J., McPeters, R. D., and Stolarski, R.: Global and zonal total ozone variations estimated from ground-based and satellite measurements: 1964-2000, J. Geophys. Res., 107, 4647, doi:10.1029/2001JD001350, 2002.

Fleming, E. L., Chandra, S., Barnett, J. J., and Corney, M.: Zonal mean temperature, pressure, zonal wind, and geopotential height as functions of latitude, COSPAR International Reference Atmosphere: 1986, Part II: Middle Atmosphere Models, Adv. Space Res., 10, 11-59, 1990.

Forster, P. M. de F. and Shine, K. P.: Radiative forcing and temperature trends from stratospheric ozone trends, J. Geophys. Res., 102, 10 841-10 855, 1997.

Garcia, R. R., Marsh, D. R., Kinnison, D. E., Boville, B. A., and Sassi, F.: Simulation of secular trends in the middle atmosphere, 1950-2003, J. Geophys. Res., 112, D09301, doi:10.1029/2006JD007485, 2007.

Giorgetta, M. A., Manzini, E., Roeckner, E., Esch, M., and Bengtsson, L.: Climatology and forcing of the quasi-biennial oscillation in the MAECHAM5 model, J. Climate, 19, 3882-3901, 2006.

Gleason, J. F., Bhatia, P. K., Herman, J. R., McPeters, R., Newman, P., Stolarski, R. S., Flynn, L., Labow, G., Larko, D., Seftor, C., Wellemeyer, C., Komhyr, W. D., Miller, A. J., and Planet, W.: Record low global ozone in 1992, Science, 260, 523-526, 1993.

Gray, L. J. and Dunkerton, T. J.: The role of the seasonal cycle in the quasi-biennial oscillation of ozone, J. Atmos., Sci., 47, 24292451, 1990.

Hadjinicolaou, P., Pyle, J. A., and Harris, N. R. P.: The recent turnaround in stratospheric ozone over northern middle latitudes: A dynamical modeling perspective, Geophys. Res. Lett., 32, L12821, doi:10.1029/2005GL022476, 2005.

Hamilton, K.: Effects of an imposed quasi-biennial oscillation in a comprehensive troposphere-stratosphere-mesosphere general circulation model, J. Atmos. Sci., 55, 2393-2418, 1998.

Hampson, J. and Haynes, P.: Influence of the equatorial QBO on the extratropical stratosphere, J. Atmos. Sci., 63, 936-951, 2006.
Hasebe, F.: Quasi-biennial oscillations of ozone and diabatic circulation in the equatorial stratosphere, J. Atmos. Sci., 51, 729-745, 1994.

Haynes, P. H., Marks, C. J., McIntyre, M. E., Shepherd, T. G., and Shine, K. P.: On the "downward control" of extratropical diabatic circulation by eddy-induced mean zonal forces, J. Atmos. Sci., 48, 651-678, 1991.

Hines, C. O.: Doppler-spread parameterization of gravity-wave momentum deposition in the middle atmosphere. Part 2. Broad and quasi monochromatic spectra, and implementation, J. Atmos. Solar-Terr. Phy., 59, 387-400, 1997.

Holton, J. R. and Tan, H.-C.: The influence of the equatorial QuasiBiennial Oscillation on the global circulation at $50 \mathrm{mb}$, J. Atmos. Sci., 37, 2200-2208, 1980.

Holton, J. R. and Austin, J.: The influence of the equatorial QBO on sudden stratospheric warmings, J. Atmos. Sci., 48, 607-618, 1991.

Hood, L. L.: Effects of solar UV variability on the stratosphere, in: Solar variability and its effect on climate, edited by: Pap, J. M., Fox, P., Frohlich, C., Hudson, H. S., Kuhn, J., McCormack, J., North, G., Sprigg, W., and Wu, S. T., AGU Monograph 141, American Geophysical Union, Washington D.C., 283-303, 2004.

IPCC (Intergovernmental Panel on Climate Change): Climate change 2001: The scientific basis. Contribution of Working Group 1 to the Third Assessment Report, J. T. Houghton (Eds.), Cambridge University Press, Cambridge, United Kingdom and New York, NY, USA, 2001.

Jackman, C. H., Fleming, E. L., Chandra, S., Considine, D. B., and Rosenfield, J. E.: Past, present, and future modeled ozone trends with comparisons to observed trends, J. Geophys. Res., 101, 28 753-28767, 1996.

Kalnay, E., Kanamitsu, M., Kistler, R., Collins, W., Deaven, D., Gandin, L., Iredell, M., Saha, S., White, G., Woolen, J., Zhu, Y., Chelliah, M., Ebisuzaki, W., Higgins, W., Janowiak, J., Mo, K. C., Ropelewski, C., Wang, J., Leetma, A., Reynolds, R., Jenne, R., and Joseph, D.: The NCEP/NCAR 40-year reanalysis project, B. Am. Meteorol. Soc., 77, 437-471, 1996.

Kinnersley, J. S. and Tung, K. K.: Mechanisms for the extratropical QBO in circulation and ozone, J. Atmos. Sci., 56, 1942-1962, 1999.

Kinnison, D. E., Grant, K. E., Connell, P. S., Rotman, D. A., and Wuebbles, D. J.: The chemical and radiative effects of the Mount Pinatubo eruption, J. Geophys. Res., 99, 25 705-25 731, 1994.

Kirchner, I., Stenchikov, G. L., Graf, H.-F., Robock, A., and Antuña, J. C.: Climate model simulation of winter warming and summer cooling following the 1991 Mount Pinatubo volcanic eruption, J. Geophys. Res., 104, 19039-19055, doi:10.1029/1999JD900213, 1999.

Kodera, K. and Kuroda, Y.: Dynamical response to the solar cycle, J. Geophys. Res., 107, 4749, doi:10.1029/2002JD002224, 2002.

Labitzke, K.: Sunspots, the QBO and the stratospheric temperature in the north polar region, Geophys, Res. Lett., 14, 535-537, 1987.

Labitzke, K. and McCormick, M. P.: Stratospheric temperature increases due to Pinatubo aerosols. Geophys. Res. Lett., 19, 207210, 1992.

Labitzke, K., Austin, J., Butchart, N., Knight, J., Takahashi, M., Nakamoto, M., Nagashima, T., Haigh, J., and Williams, V.: The global signal of the 11-year solar cycle in the stratosphere: ob- 
servations and models, J. Atmos. Terr. Phys., 64, 203-210, 2002.

Labitzke, K. and van Loon, H.: Associations between the 11-year solar cycle, the QBO and the atmosphere, Part I: The troposphere and stratosphere in the northern hemisphere in winter, J. Atmos. Terr. Phys., 50, 197-206, 1988.

Lacis, A. A., Wuebbles, D. J., and Logan, J. A.: Radiative forcing of climate by changes in the vertical distribution of ozone, J. Geophys. Res., 95, 9971-9981, 1990.

Lean, J. L., Rottman, G. J., Kyle, H. L., Woods, T. N., Hickey, J. R., and Puga, L. C.: Detection and parameterization of variations in solar mid- and near-ultraviolet radiation (200-400 nm), J. Geophys. Res., 102, 29 939-29956, 1997.

Lee, H. and Smith, A. K.: Simulation of the combined effects of solar cycle, quasi-biennial oscillation, and volcanic forcing on stratospheric ozone changes in recent decades, J. Geophys. Res., 108, 4049, doi:10.1029/2001JD001503, 2003.

Ling, X.-D. and London, J.: The quasi-biennial oscillation of ozone in the tropical middle stratosphere: A one-dimensional model, J. Atmos. Sci., 43, 3122-3137, 1986.

Logan, J. A., Jones, D. B. A., Megretskaia, I. A., Oltmans, S. J., Johnson, B. J., Vömel, H., Randel, W. J., Kimani, W., and Schmidlin, F. J.: Quasibiennial oscillation in tropical ozone as revealed by ozonesonde and satellite data, J. Geophys. Res., 108, 4244, doi:10.1029/2002JD002170, 2003.

McCormack, J. P. and Hood, L. L.: Apparent solar cycle variations of upper stratospheric ozone and temperature: Latitude and seasonal dependences, J. Geophys. Res., 101, 20 933-20 944, 1996.

McCormick, M. P., Zawodny, J. M., Viega, R. E., Larson, J. C., and Wang, P. H.: An overview of SAGE I and II ozone measurements, Planet. Space Sci., 37, 1567-1586, 1989.

Mote, P. W., Rosenlof, K. H., McIntyre, M. E., Carr, E. S., Gille, J. C., Holton, J. R., Kinnersley, J. S., Pumphrey, H. C., Russell III, J. M., and Waters, J. W.: An atmospheric tape recorder: The imprint of tropical tropopause temperatures on stratospheric water vapor, J. Geophys. Res., 101, 3989-4006, 1996.

Naito, Y. and Yoden, S.: A statistical analysis on the effects of the equatorial QBO on the extratropical stratosphere and troposphere based on large samples of daily data, SOLA, 1, 17-20, doi:10.2151/sola.2005-005, 2005.

Newman, P. A., Kawa, S. R., and Nash, E. R.: On the size of the Antarctic ozone hole, Geophys. Res. Lett., 31, L21104, doi:10.1029/2004GL020596, 2004.

Newman, P. A., Nash, E. R., Kawa, S. R., Montzka, S. A., and Schauffler, S. M.: When will the the Antarctic ozone hole recover?, Geophys. Res. Lett., 33, L12814, doi:10.1029/2005GL025232, 2006.

Newchurch, M. J., Yang, E.-S., Cunnold, D. M., Reinsel, G. C., Zawodny, J. M., and Russell III, J. M.: Evidence for slowdown in stratospheric ozone loss: First stage of ozone recovery, J. Geophys. Res., 108, 4507, doi:10.1029/2003JD003471, 2003.

Pascoe, C. L., Gray, L. J., Crooks, S. A., Juckes, M. N., and Baldwin, M. P.: The quasi-biennial oscillation: Analysis using ERA-40 data, J. Geophys. Res., 110, D08105, doi:10.1029/2004JD004941, 2005.

Pawson, S., Kodera, K., Hamilton, K., Shepherd, T. G., Beagley, S. R., Boville, B. A., Farrara, J. D., Fairlie, T. D. A., Kitoh, A., Lahoz, W. A., Langematz, U., Manzini, E., Rind, D. H., Scaife, A. A., Shibata, K., Simon, P., Swinbank, R., Takacs, L., Wilson, R. J., Al-Saadi, J. A., Amodei, M., Chiba, M., Coy, L., de Grandpre,
J., Eckman, R. S., Fiorino, M., Grose, W. L., Koide, H., Koshyk, J. N., Li, D., Lerner, J., Mahlman, J. D., McFarlane, N. A., Mechoso, C. R., Molod, A., O’Neill, A., Pierce, R. B., Randel, W. J., Rood, R. B., and Wu, F.: The GCM-Reality Intercomparison Project for SPARC: scientific issues and initial results, B. Am. Meteorol. Soc., 81, 781-796, 2000.

Philander, S. G.: El Niño, La Niña, and the Southern Oscillation, International Geophysics Series, 46, Academic Press, San Diego, USA, 1989.

Plumb, R. A. and Bell, R. C.: A model of the quasi-biennial oscillation on an equatorial beta-plane, Q. J. Roy. Meteorol. Soc., 108, $335-352,1982$.

Randel, W. J. and Cobb, J. B.: Coherent variations of monthly mean total ozone and lower stratospheric temperature, J. Geophys. Res., 99, 5433-5447, 1994.

Randel, W. J. and Wu, F.: Isolation of the ozone QBO in SAGE II data by singular-value decomposition, J. Atmos. Sci., 53, 25462559, 1996.

Randel, W. J. and Wu, F.: Cooling of the arctic and antarctic polar stratospheres due to ozone depletion, J. Climate, 12, 1467-1479, 1999.

Randel, W. J. and Wu, F.: A stratospheric ozone profile data set for 1979-2005: variability, trends, and comparisons with column ozone data, J. Geophys. Res., 112, D06313, doi:10.1029/2006JD007339, 2007.

Randel, W. J., Wu, F., Russell III, J. M., Waters, J. W., and Froidevaux, L.: Ozone and temperature changes in the stratosphere following the eruption of Mt. Pinatubo, J. Geophys. Res., 100, 16753-15 764, 1995.

Randel, W. J., Wu, F., Swinbank, R., Nash, J., and O'Neill, A.: Global QBO circulation derived from UKMO stratospheric analyses, J. Atmos. Sci., 56, 457-474, 1999.

Rayner, N. A., Parker, D. E., Horton, E. B., Folland, C. K., Alexander, L. V., Rowell, D. P., Kent, E. C., and Kaplan, A.: Global analyses of sea surface temperature, sea ice, and night marine air temperature since the late nineteenth century, J. Geophys. Res. 108, 4407, doi:10.1029/2002JD002670, 2003.

Reid, G. C.: Seasonal and interannual temperature variations in the tropical stratosphere, J. Geophys. Res., 99, 18 923-18 932, 1994.

Reinsel, G. C., Miller, A. J., Weatherhead, E. C., Flynn, L. E., Nagatani, R. M., Tiao, G. C., and Wuebbles, D. J.: Trend analysis of total ozone data for turnaround and dynamical contributions, J. Geophys. Res., 110, D16306, doi:10.1029/2004JD004662, 2005.

Rex, M., Salawitch, R. J., Deckelmann, H., von der Gathen, P., Harris, N. R. P., Chipperfield, M. P., Naujokat, B., Reimer, E., Allaart, M., Andersen, S. B., Bevilacqua, R., Braathen, G. O., Claude, H., Davies, J., De Backer, H., Dier, H., Dorokhov, V., Fast, H., Gerding, M., Godin-Beekmann, S., Hoppel, K., Johnson, B., Kyrö, E., Litynska, Z., Moore, D., Nakane, H., Parrondo, M. C., Risley Jr., A. D., Skrivankova, P., Stübi, R., Viatte, P., Yushkov, V., and Zerefos, C.: Arctic winter 2005: Implications for stratospheric ozone loss and climate change, Geophys. Res. Lett., 33, L23808, doi:10.1029/2006GL026731, 2006.

Russell III, J. M., Gordley, L. L., Park, J. H., Drayson, S. R., Hesketh, W. D., Cicerone, R. J., Tuck, A. F., Frederick, J. E., Harries, J. E., and Crutzen, P. J.: The Halogen Occultation Experiment, J. Geophys. Res., 98, 10777-10 797, 1993.

Sato, M., Hansen, J. E., McCormick, M. P., and Pollack, J. B.: Stratospheric aerosol optical depths, 1850-1990, J. Geophys. 
Res., 98, 22 987-22 994, 1993.

Scaife A. A., Austin, J., Butchart, N., Pawson, S., Keil, M., Nash, J., and James, I. N.: Seasonal and interannual variability of the stratosphere diagnosed from UKMO TOVS analyses, Q. J. Roy. Meteor. Soc., 126, 2585-2604, 2000.

Sekiyama, T. T., Shibata, K., Deushi, M., Kodera, K., and Lean, J. L.: Stratospheric ozone variation induced by the 11-year solar cycle: recent 22-year simulation using 3-D chemical transport model with reanalysis data, Geophys. Res. Lett., 33, L17812, doi:10.1029/2006GL026711, 2006.

Shibata, K., Yoshimura, H., Ohizumi, M., Hosaka, M., and Sugi, M.: A simulation of troposphere, stratosphere and mesosphere with an MRI/JMA98 GCM, Pap. Meteorol. Geophys., 50, 1553, 1999.

Shibata, K. and Kodera, K.: Simulation of radiative and dynamical responses of the middle atmosphere to the 11year solar cycle, J. Atmos. Terr. Phys., 67, 125-143, doi:10.1016/j.jastp.2004.07.022, 2005.

Shibata, K. and Deushi, M.: Partitioning between resolved wave forcing and unresolved gravity wave forcing to the quasi-biennial oscillation as revealed with a coupled chemistry-climate model, Geophys. Res. Lett., 32, L12820, doi:10.1029/2005GL022885, 2005a.

Shibata, K. and Deushi, M.: Radiative effect of ozone on the quasibiennial oscillation in the equatorial stratosphere, Geophys. Res. Lett., 32, L24802, doi:10.1029/2005GL023433, 2005b.

Shibata, K. K., Deushi, M., Sekiyama, T. T., and Yoshimura, H.: Development of an MRI chemical transport model for the study of stratospheric chemistry, Pap. Meteorol. Geophys., 55, 75-119, 2005.

Siebert, L. and Simkin, T.: Volcanoes of the World: an Illustrated Catalog of Holocene Volcanoes and their Eruptions, Smithsonian Institution, Global Volcanism Program Digital Information Series, GVP-3, available at: http://www.volcano.si.edu/world/, 2002.

Sigmond, M., Siegmund, P. C., Manzini, E., and Kelder, H.: A simulation of the separate climate effects of middle atmospheric and tropospheric CO2 doubling, J. Climate, 17, 2352-2367, 2004.

SPARC: SPARC/IOC/GAW Assessment of Trends in the Vertical Distribution of Ozone, SPARC Report No. 1, WMO Global Ozone Research and Monitoring Project-Report No. 43, 1998.
Stolarski, R. S., Douglass, A. R., Steenrod, S., and Pawson, S.: Trends in stratospheric ozone: Lessons learned from a 3D chemical transport model, J. Atmos. Sci., 63, 1028-1041, 2006.

Takahashi, M.: Simulation of the stratospheric quasi-biennial oscillation in a general circulation model, Geophys. Res. Lett., 26, 1307-1310, 1999.

Taylor, K. E., Williamson, D., and Zwiers, F.: The sea surface temperature and sea-ice concentration boundary conditions for AMIP II simulations, PCMDI Report No. 60, Program for Climate Model Diagnosis and Intercomparison, Lawrence Livermore National Laboratory, Livermore, California, 25 pp, 2000.

Tian, W. and Chipperfield, M. P.: A new coupled chemistry-climate model for the stratosphere: The importance of coupling for future O3-climate predictions, Q. J. Roy. Meteorol. Soc., 131, 281-303, 2005.

Tie, X. X., Brasseur, G. P., Briegleb, B., and Granier, C.: Twodimensional simulation of Pinatubo aerosol and its effect on stratospheric ozone, J. Geophys. Res., 99, 20 545-20 562, 1994.

Tourpali, K., Schuurmans, C. J. E., van Dorland, R., Steil, B., and Brühl, C.: Stratospheric and tropospheric response to enhanced solar UV radiation: A model study, Geophys. Res. Lett., 30, 1231, doi:10.1029/2002GL016650, 2003.

Uppala, S. M., Kållberg, P. W., Simmons, A. J., Andrae, U., da Costa Bechtold, V., Fiorino, M., Gibson, J. K., Haseler, J., Hernandez, A., Kelly, G. A., Li, X., Onogi, K., Saarinen, S., Sokka, N., Allan, R. P., Andersson, E., Arpe, K., Balmaseda, M. A., Beljaars, A. C. M., van de Berg, L., Bidlot, J., Bormann, N., Caires, S., Chevallier, F., Dethof, A., Dragosavac, M., Fisher, M., Fuentes, M., Hagemann, S., Holm, E., Hoskins, B. J., Isaksen, L., Janssen, P. A. E. M., Jenne, R., McNally, A. P., Mahfouf, J.-F., Morcrette, J.-J., Rayner, N. A., Saunders, R. W., Simon, P., Ster, A., Trenberth, K. E., Untch, A., Vasiljevic, D., Viterbo, P., and Woollen, J.: The ERA-40 Reanalysis, Q. J. Roy. Meteor. Soc., 131, 2961-3012, doi:10.1256/qj.04.176, 2005.

World Meteorological Organization (WMO)/United Nations Environment Programme (UNEP): Scientific Assessment of Ozone Depletion: 2002, World Meteorological Organization, Global Ozone Research and Monitoring Project, Report No. 47, Geneva, Switzerland, 2003.

Xiao, F. and Peng, X.: A convexity preserving scheme for conservative advection transport, J. Comput. Phys., 198, 389-402, doi:10.1016/j.jcp.2004.01.013, 2004. 